\title{
Geotechnical Reconnaissance of the 2002 Denali Fault, Alaska, Earthquake
}

\author{
Robert Kayen, ${ }^{\text {a) }}$ M.EERI, Eric Thompson, ${ }^{\text {a) }}$ Diane Minasian,,${ }^{\text {a) }}$ \\ Robb E. S. Moss, ${ }^{\text {b) }}$ M.EerI, Brian D. Collins, ${ }^{\text {b) }}$ Nicholas Sitar, ${ }^{\text {b) }}$ M.EeRI, \\ Douglas Dreger, ${ }^{\text {b) }}$ and Gary Carver ${ }^{\mathrm{c})}$
}

The 2002 M7.9 Denali fault earthquake resulted in $340 \mathrm{~km}$ of ruptures along three separate faults, causing widespread liquefaction in the fluvial deposits of the alpine valleys of the Alaska Range and eastern lowlands of the Tanana River. Areas affected by liquefaction are largely confined to Holocene alluvial deposits, man-made embankments, and backfills. Liquefaction damage, sparse surrounding the fault rupture in the western region, was abundant and severe on the eastern rivers: the Robertson, Slana, Tok, Chisana, Nabesna and Tanana Rivers. Synthetic seismograms from a kinematic source model suggest that the eastern region of the rupture zone had elevated strong-motion levels due to rupture directivity, supporting observations of elevated geotechnical damage. We use augered soil samples and shear-wave velocity profiles made with a portable apparatus for the spectral analysis of surface waves (SASW) to characterize soil properties and stiffness at liquefaction sites and three trans-Alaska pipeline pump station accelerometer locations.

\section{THE DENALI FAULT EARTHQUAKE}

On the afternoon of 3 November 2003, a M7.9* earthquake ruptured the Susitna Glacier fault, the Denali fault, and the Totschunda fault. The M7.9 main shock was preceded by a M6.7 foreshock on October 23, 2002 (Figure 1), on a 45-kilometer segment of the Denali fault (Eberhart-Phillips et al. 2003, Wright et al. 2003). The epicenter of the main shock was $22 \mathrm{~km}$ east of the foreshock, and consisted of multiple subevents that Eberhart-Phillips et al. (2003) relate to regions of high slip along the three faults. The first sub-event was a M7.2 thrust on $40 \mathrm{~km}$ of the previously unknown Susitna Glacier fault (Figure 1). The second sub-event was a result of right-lateral (dextral) rupture on the Denali fault in the vicinity of where the Black Rapids Glacier crosses the TransAlaska Pipeline System (TAPS) and was equivalent to a M7.3. This second subevent produced a large velocity pulse recorded nearby at TAPS Pump Station 10 (station PS10). The peak acceleration and velocity at PS10 were the highest recorded for the earthquake at $0.36 \mathrm{~g}$ and $114 \mathrm{~cm} / \mathrm{s}$ (high-pass-filtered values), respectively (Ellsworth et al., this issue; and Figure 1). The third sub-event (Figure 1) covered $140 \mathrm{~km}-220 \mathrm{~km}$ east of the hypocenter in the region east of the pipeline between the Canwell Glacier and

a) United States Geological Survey, 345 Middlefield Road, Menlo Park, CA 94025

b) University of California at Berkeley, Berkeley, CA 94720

c) Carver Geologic, Inc., P.O. Box 52, Kodiak, AK 99615

* All magnitudes in this paper, unless otherwise indicated, are moment magnitudes, M. 


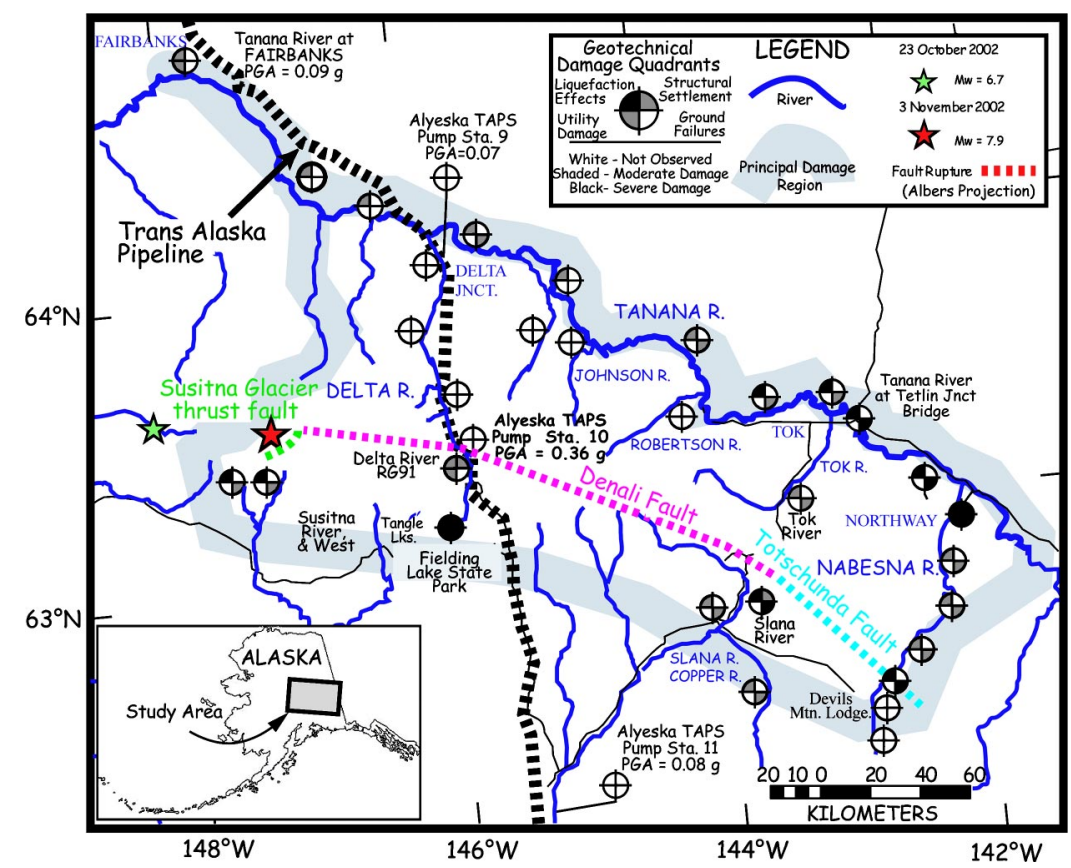

Figure 1. Geotechnical affects of the 3 November 2002, M7.9 Denali fault earthquake. Peak ground accelerations are presented for Fairbanks and Alyeska Pipeline Service Company facilities. The region of damaged ground covered over a $500 \mathrm{~km}$ wide swath of central Alaska. Details of the severity of damage effects are reported in damage quadrants described in the map legend.

the town of Mentasta. This dextral offset sub-event on the Denali fault had a large displacement pulse, and was followed by a right step-over zone to the Totschunda fault where surface displacements were sharply diminished over a $76-\mathrm{km}$ portion of the Totshunda fault. The total $340-\mathrm{km}$ surface rupture was unidirectional from west to east. The seismic moment inverted from the geodetic and strong-motion data is estimated to be between M7.8 and M7.9 (Eberhart-Phillips et al. 2003). The overall duration of shaking was about $140 \mathrm{~s}$ with individual sub-event displacement pulses having periods of 20-30 s.

Because of the remote location of this M7.9 earthquake, the cost to lives and property was remarkably low. There were no fatalities, only one injury, and damage was estimated at approximately $\$ 40$ million dollars. The fault ruptured beneath the transAlaska pipeline at pipeline mile marker 591 with about $5.8 \mathrm{~m}$ of dextral slip distributed across several en-echelon step-overs. The pipeline's earthquake monitoring system (and Alyeska personnel) initiated an automated shutdown after the earthquake. Within several kilometers of the rupture zone, eight horizontal support beams for the pipeline and nine anchored support structures were damaged where the pipe was elevated, causing the pipeline to sag in a few places. Where the pipeline was free to slide on horizontal beams, with Teflon shoes, high-velocity lateral movement of the pipeline caused pounding dam 
age to several vertical support bars. In addition, some settlement of the pipeline occurred in liquefied backfill about 1.5 kilometers south of the fault rupture at regulator valve 91. The trans-Alaska pipeline, designed to withstand $6.1 \mathrm{~m}$ of dextral slip at this location, and to withstand the shaking duration and motion associated with a M8.0 earthquake, withstood the M7.9 earthquake with little damage and no spillage of oil.

\section{LIQUEFACTION AND RELATED GROUND DEFORMATION}

Widespread liquefaction within alluvial deposits of rivers and streams in and adjacent to the central Alaska Range generated lateral-spreading cracks and sand boils. Along with liquefaction-related features, the earthquake triggered landslides, consisting mainly of rock falls and massive rock slides containing varying amounts of ice and snow (Harp et al. 2003). The most spectacular landslides were large rock avalanches that spread onto glaciers, for example, the West Fork landslide, the Black Rapids Glacier landslide, and the McGinnis Peak landslide. With only one strong-motion accelerograph recording near the earthquake rupture and only a few felt reports from the sparsely populated area, the patterns of triggered landslides and liquefaction effects may be among the best indicators of the pattern of ground shaking.

Liquefaction-induced ground failures were observed throughout east-central Alaska, to distances well beyond the narrow $30-\mathrm{km}$ limit of landslides straddling the rupture zone. Seismic triggering of soil liquefaction occurs in buried layers of unconsolidated, water-saturated silts, sand and gravely sand during prolonged shaking in an earthquake. For liquefaction to occur, the sediment particles in a buried layer reorient themselves to occupy less space (that is, the solid particles' framework contracts) and force a reduction of water-filled pore space. A transient elevation of pore-water pressure and a sharp loss of soil strength results from this contraction. Overlying layers that are unsaturated, more consolidated, or frozen become rafted and destabilized on the momentarily softened liquefied soil layer, and fracture to allow the water and fluidized sand to escape through fissures to form sand boils. Where slopes gravitationally stress the soil, liquefaction can cause surface layers to slide downhill (in lateral-spreading failures). Liquefaction from the Denali fault earthquake induced debris flows, lateral-spreading ground failures, sand boils and fissures.

The distribution of liquefaction effects depended also upon the location of susceptible deposits with respect to the fault. These deposits, mainly alluvium, were along the central Alaska Range rivers but also included lake-margin sediment and artificial fill. Reconnaissance by air and by driving the road network from Parks Highway into Yukon Territory, Canada, suggested that liquefaction effects extended out from the surface rupture for approximately $100 \mathrm{~km}-120 \mathrm{~km}$. In addition to liquefaction features, both soil slides and soil flows were observed within fine-grained deposits (possibly glacial rock flour) along the banks of the Nelchina River south of Glenn Highway, approximately 200 $\mathrm{km}$ from the zone of fault rupture (Harp et al. 2003).

\section{RECONNAISSANCE METHOD}

Immediately following the earthquake, a reconnaissance team sponsored by the National Science Foundation (NSF) and the U.S. Geological Survey (USGS) was sent to the 
faulted region to assess the geotechnical aspects of this event. The team's focus was to quantify the spatial extent and amplitude of geotechnical damage, namely ground failures and soil liquefaction, and the associated damage to lifeline systems and structures. During the November reconnaissance, three fixed-wing flights over the fault rupture region and river systems draining the central Alaska Range were followed by a groundlevel reconnaissance of the areas accessible by car. During the flights we were able to document the broad spatial extent of liquefaction features on the Holocene river deposits of the central range, and the region of lake-ice cracking. These flights allowed us to target the locations of the ground-level investigations in November 2002 and July 2003.

On the ground, we sought to quantify the severity and abundance of liquefaction features, lateral displacements, and fissures. We mapped the spatial pattern of fissures and the location of sand boil fields using a digital mapping tablet and a differential GPS unit. This allowed us to annotate the digital files directly, with survey tracklines, and comment on the observed damage. The digital mapping system we used couples Strata Software's PenMap software and GeoMapper real-time mapping and monitoring freeware with a 32-bit tablet computer with Windows' graphical user interfaces (GUI), a survey-grade differential-capable global positioning system (DGPS) unit, and a satellite-based GPS differential signal to obtain decimeter precision levels during mobile positioning surveys. The mapping unit is lightweight and carried on a backpack. One surveyor was put in charge of conducting the DGPS field surveys while the other team members performed sampling and measurement tasks (Figure 2).

Physical sampling of surface ejecta at sand boils and fissures frozen after the event required hammers and sharp digging tools. During the July 2003 fieldwork, hand augured samples to $5 \mathrm{~m}$ depth were recovered from the ground using a sand sampling auger bit. A total of 35 soil ejecta sites were analyzed using samples taken on or near the Slana River, the Nabesna River and the Nabesna-Chisana confluence at the village of Northway, the Tok River, the Gerstle River, the Delta River, the Susitna River, and Fielding Lake State Park. Soil classification results from geotechnical laboratory testing are included in Table AI in Appendix 1 for 35 samples obtained during the reconnaissance. Grain size distribution curves for all the samples are grouped by general location and are included in Appendix 2.

We characterized the resistance to liquefaction of the soil profile by measuring the stiffness properties (shear-wave velocity $V_{s}$ ) of the upper $30 \mathrm{~m}$ of the ground. To do this efficiently without invasive drilling, we used a variety of surface wave techniques including transient source Spectral Analysis of Surface Waves (SASW) and continuous harmonic-wave SASW to capture the characteristics of phase velocity with dispersion. From the dispersion data, we computed the shear-wave velocity structure by inversion. Many of the sites we tested consist of gravels and gravely sands, and surface wave methods were especially useful for profiling these deposits. The apparatus we used for SASW investigations is lightweight, portable, and easily deployable by one or two people. For remote site investigations where transport by backpack or helicopter was necessary, we carried a sledgehammer source, $1-\mathrm{Hz}$ seismometers, and a spectrum analyzer powered by car battery (Figure 3). For most locations a field vehicle could be driven to within 100 meters of the site, and far cleaner phase-velocity data were obtained using a continuous harmonic-wave source (Figure 4). 

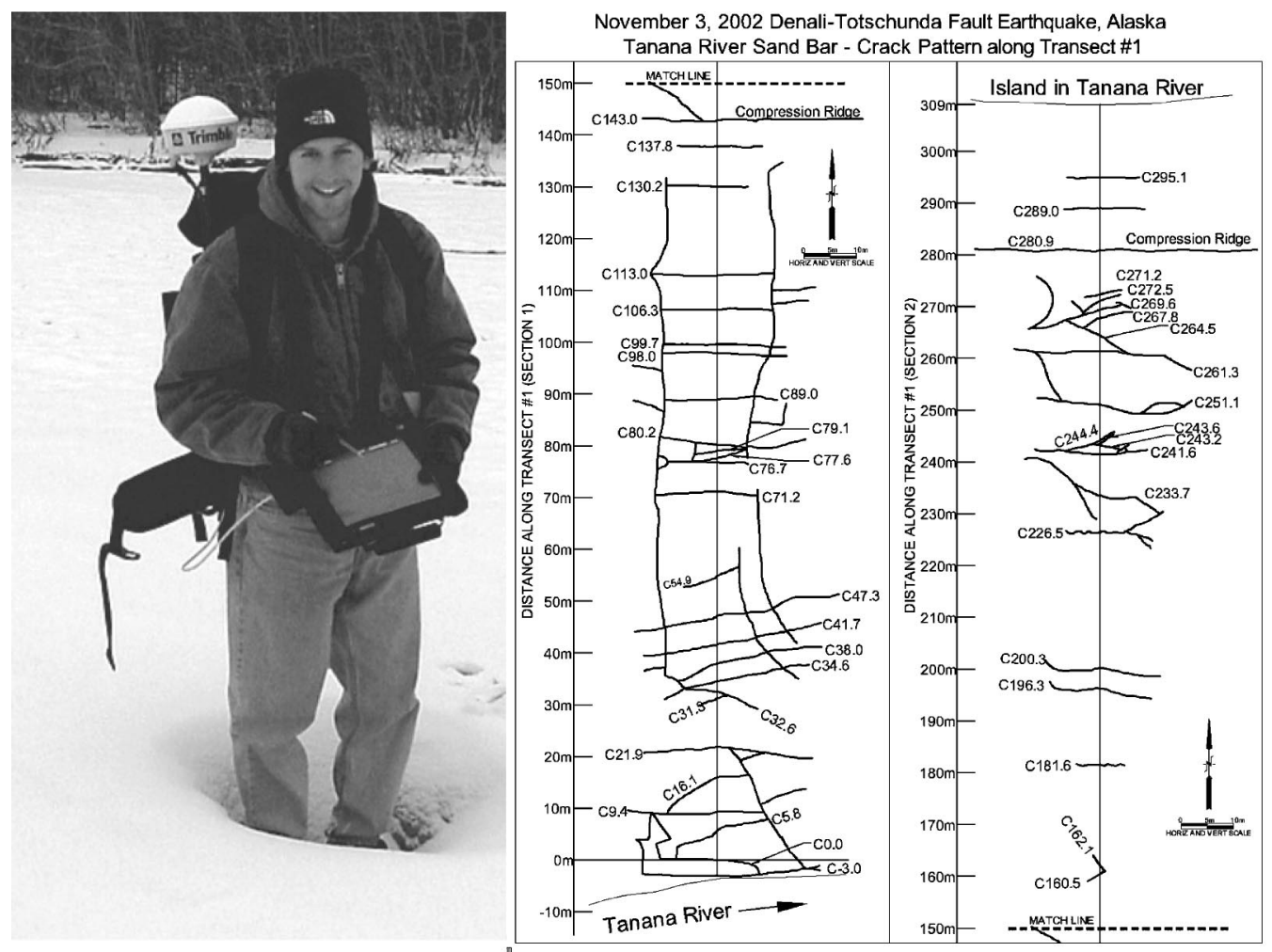

Figure 2. Medium precision (decimeter-scale) surveys were made using a portable differential GPS mapping unit. On the right is a detail map of lateral spreads on the Tanana River at Tetlin Junction (near SASW Site 588-TET).

For the Alyeska Pipeline Services Company (hereafter, Alyeska) facilities we used the continuous harmonic wave SASW approach, and at Pump Station 9 (station PS9) we passively recorded microtremors produced by the jet-turbine pump-house. At PS9, we merged and averaged the passive and active source dispersion curves, whereas at all other sites we averaged only active source dispersion data. To produce a site curve we merged all of the array-specific data $(2 \mathrm{~m}, 4 \mathrm{~m}, 8 \mathrm{~m}, 16 \mathrm{~m}, 32 \mathrm{~m}$, and so on) for the forward and reverse directions and calculated an average dispersion curve.

Inversion of a shear-wave profile from the phase velocity vs. dispersion curve is a process of determining a theoretical shear-wave velocity structure whose dispersion characteristics match the experimental dispersion measurements. This is performed using a non-biased numerical approach that iterates toward a constrained least-squares fit between the theoretical and experimental data (Kayen et al. 2003, Rix et al. 2002). The liquefaction assessment of the ground using shear-wave velocity is a process in which the soil capacity to resist liquefaction is compared with the estimated loads put on the soil mass by earthquake shaking. Here, soil capacity is measured by shear-wave velocity, and load is estimated using the commonly adopted cyclic stress ratio (CSR, Youd et al. 2001). 


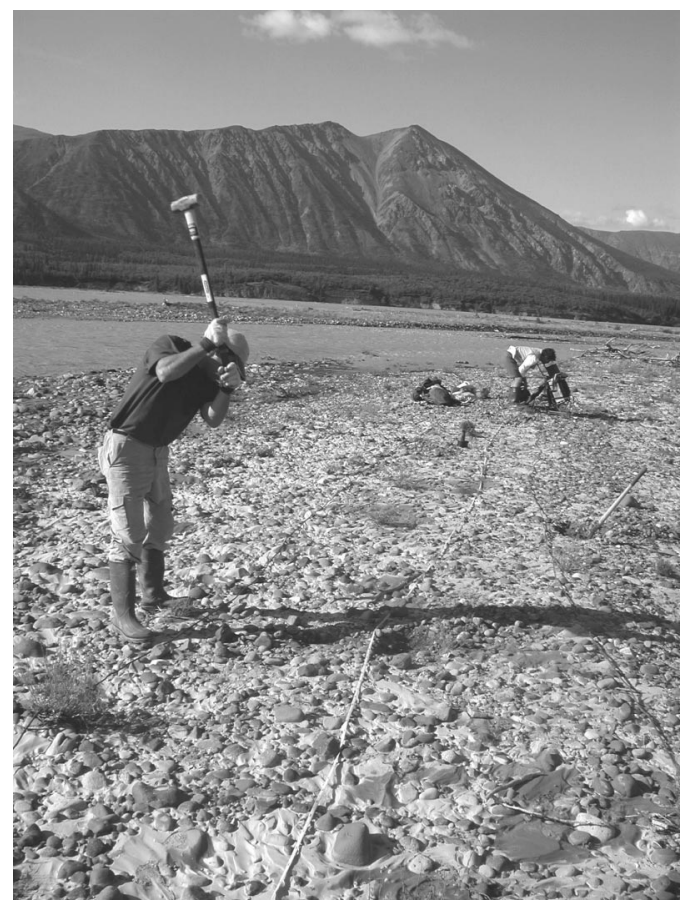

Figure 3. Hammer source SASW testing at site 583-NAB on the Nabesna River, a nonliquefaction site.

\section{HOLOCENE RIVER DEPOSITS}

\section{TANANA RIVER}

On the north side of the Alaska Range in the Tanana River valley, $50 \mathrm{~km}$ to $120 \mathrm{~km}$ from the zone of fault rupture, we saw extensive evidence of liquefaction where fluvial deposits of sand and silt were capped by a thin (less than 0.3-m thick) frozen surface layer (Figure 1). Liquefaction within the Tanana River valley was widespread from isolated fissures and sand boils in Fairbanks, on the west, to at least several hundred kilometers eastward. Liquefaction damage became increasingly severe east of Delta Junction, even as the distance from the fault increased. In the Tok area, nearly every river bar contained extensive liquefaction effects (Figure 5). Farther east, for many kilometers around the town of Northway, large continuous lowland areas of liquefaction and lateralspread failures were observed.

Two DGPS-measured transects along the Tanana River at Tetlin Bridge, west of Tok, showed lateral strains of 3\%-4\% on sand bars across distances of $200 \mathrm{~m}$ ( 21 fissures) and $400 \mathrm{~m}$ (48 fissures) (Figures 2 and 5). In some places the frozen crust (less than 0.3-m thick) of separate lateral spreads decoupled from the underlying soil and collided, buckled and thrust over one another resulting in contractions of as much as $4.5 \mathrm{~m}$ (Figure 6). 


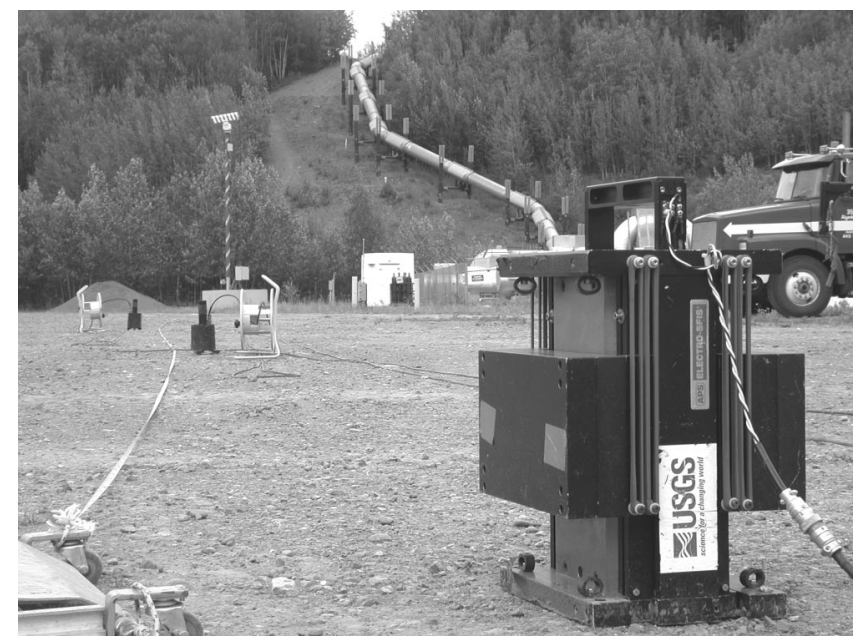

Figure 4. The preferred method of SASW testing uses a continuous harmonic-wave source produced by a low-frequency computer-controlled electromechanical shaker (device at right) and multi-sensor linear seismometer arrays (2-sensors on the left). This site is 600-PS11, at Trans Alaska Pipeline, Alyeska Pump Station 11, Glennallen, Alaska.

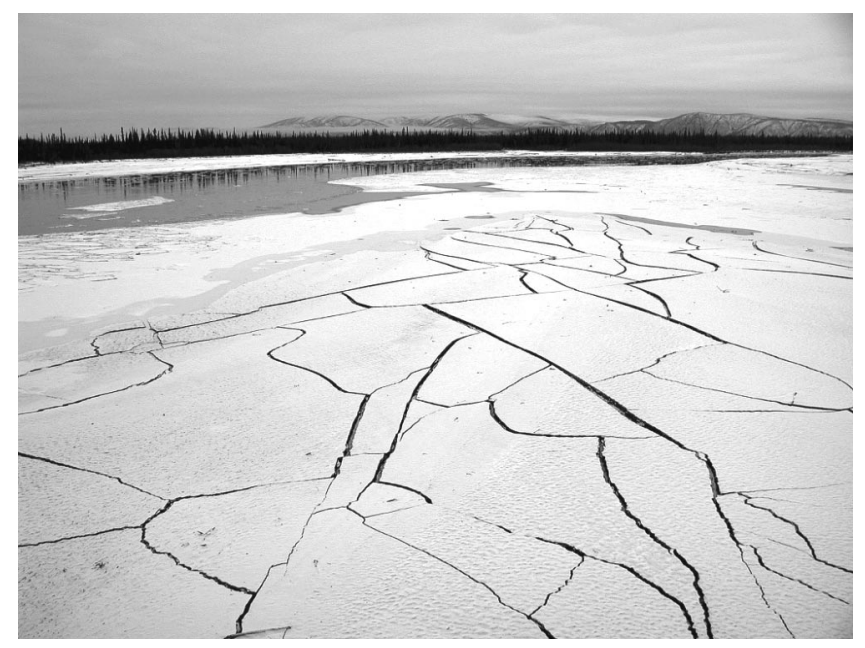

Figure 5. Lateral spreads on bars of the Tanana River. The crust of the bar was frozen to a depth of approximately 0.3 meters at the time of the earthquake and shattered in a polygonal pattern that was observed along several hundred miles of the river deposits (Site 588-TET, Tanana River, Tetlin Bridge, foreground field of view approximately 20 meters wide). 


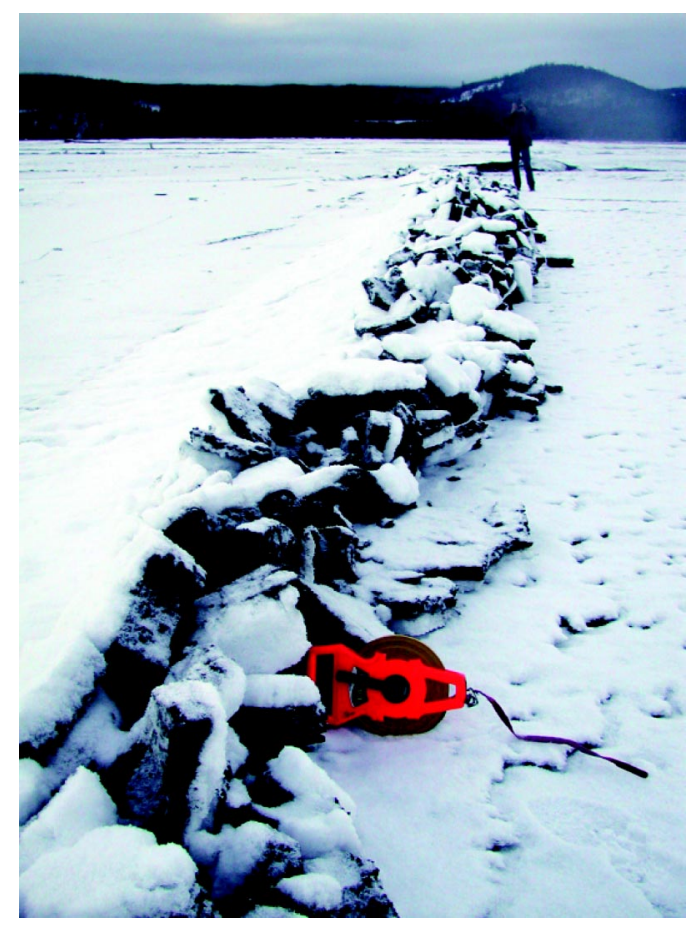

Figure 6. Lateral movement drove the crust down-slope where surface crust ( $\sim 0.3 \mathrm{~m}$ thick) was rafted on a liquefied layer. In low-areas (here, a return channel) collision of two crusts resulted in between $3.8 \mathrm{~m}$ and $4.3 \mathrm{~m}$ of shortening (near SASW Site 588-TET). The tape measure handle is $15 \mathrm{~cm}$ wide.

Parallel fissures formed locally where the ground spread laterally toward the river. More commonly the frozen ground surface displayed randomly oriented sub-planar fissures, each fissure normally less than $10 \mathrm{~cm}$ in width, forming polygonal networks that could be traced for several kilometers (Figure 7). The dimensions of the polygons in our transect surveys ranged from $0.15 \mathrm{~m}-0.3 \mathrm{~m}$ in thickness, and typically $8 \mathrm{~m}-10 \mathrm{~m}$ across the widest dimension. In total, Tanana River bar ground failures covered a vast area east of the town of Delta. Shear-wave velocities for the critical layer of liquefied soil in the Tanana River deposits at Tetlin Bridge ranged from $110 \mathrm{~m} / \mathrm{s}$ to $140 \mathrm{~m} / \mathrm{s}$.

\section{TANANA-NABESNA-CHISANA RIVER CONFLUENCE}

In the area around the village of Northway, a region of lowlands and bogs, liquefaction-related ground failures were ubiquitous. The Northway village area is 130 $\mathrm{km}-180 \mathrm{~km}$ from the sections of maximum displacement on the Denali fault and about $80 \mathrm{~km}$ from the closest point on the Totschunda fault rupture. Lateral spreading rendered the airport at Northway unusable. The frozen surface layer and paved runway at Northway were cut by fissures, many $10 \mathrm{~cm}-30 \mathrm{~cm}$ wide, with some greater than $1-\mathrm{m}$ wide, spaced meters to tens of meters apart (Figure 7). Fractures as wide as $1 \mathrm{~m}$ and as long as 


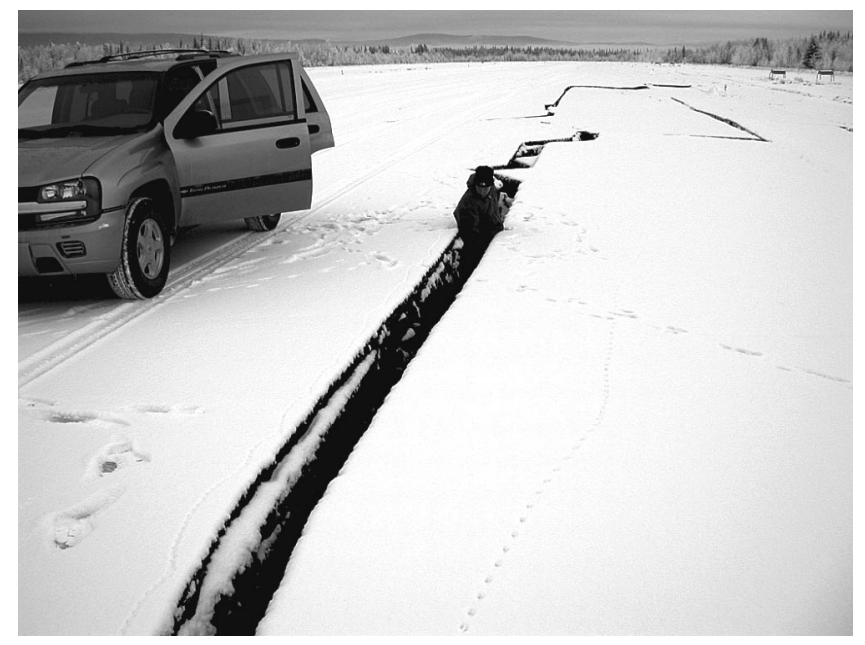

Figure 7. Fracture and lateral displacement of the northern end of the runway at Northway Airport (near SASW Site 582-NOR and 587-NOR). Fissures formed along the pavement seams of the runway.

$100 \mathrm{~m}$ opened along the perimeter of the runway and vented silt, coarse to fine sand, and pebbles.

Associated with the sand vents were sinkholes as much as $4 \mathrm{~m}$ in diameter and $1 \mathrm{~m}$ deep. Residents reported water and soil rising $2 \mathrm{~m}-4 \mathrm{~m}$ into the air during and immediately after the earthquake. Parallel and polygonal patterns of lateral spreads similar to those observed in the Tanana River bars were observed at Northway, both in the paved runways and in the surrounding undeveloped areas. Away from the runway, houses and structures were unseated and tilted on their foundations, sand boils were ubiquitous (Figure 8), and road settlements bent and crushed drainage culverts. Shear-wave velocities for the critical layer of liquefied soil at three liquefied sites near Northway Airport were low, and ranged from $90 \mathrm{~m} / \mathrm{s}$ to $150 \mathrm{~m} / \mathrm{s}$.

\section{NABESNA RIVER}

The Nabesna River emerges from its glacier approximately $20 \mathrm{~km}$ south of the Totschunda fault, and drains northward as it crosses the fault zone. The flood plain of the Nabesna River crosses over the eastern-most end of the Totschunda fault rupture. Along the path of the river the sediment deposits fine (that is, become finer) toward the north. From the glacier to within approximately $5 \mathrm{~km}$ of the south of the fault, the flood plain consists primarily of gravel and gravely sand material. In the vicinity of the fault crossing, the sediment fines from gravely sand to medium sand. To the north, the sediment continues to drop its coarse fraction and in the vicinity of Northway village the sediment deposited by the river is composed primarily of fine to medium, uniform, sand.

The pattern of liquefaction features is asymmetrical about the fault crossing. North of the Devils Mountain Lodge area, and about 5 kilometers south of the fault crossing, the soil surface features a transition from non-liquefied soil to a moderate-to-severely 


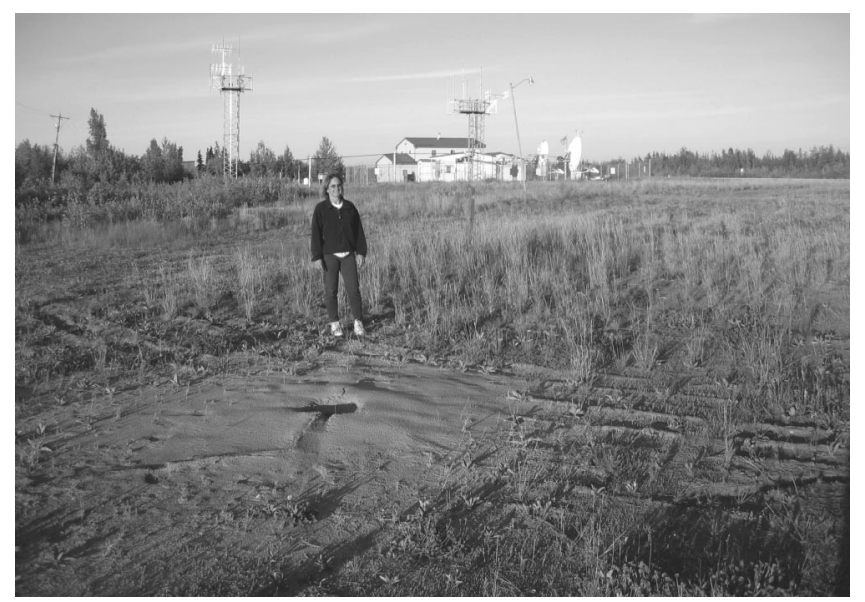

Figure 8. Sand boils west of Northway Airport were nearly perfectly preserved nine months after the earthquake when we returned to conduct SASW testing. During most of the intervening period, the ground and damage features remained frozen (SASW Site 587-NOR, Northway Weather Station).

liquefied soil across a narrow $0.5-\mathrm{km}$-wide zone. South of this location, toward the glacier, no liquefaction features were found. The most severe fissuring occurred immediately at the fault crossing, but fissures and sand vents continued at varying but lessening degrees of severity downstream to Northway, 80 kilometers distant, with only localized areas having liquefaction features.

We investigated the Nabesna River deposits with SASW and auger at five sites near the fault zone and at three sites at Northway. South of the fault crossing, the texture of the near-surface deposits became finer toward the rupture zone. The shear-wave velocities computed for five sites along the river, south of the fault, also show a steady decline in value, in the upper $6 \mathrm{~m}$ of the soil (Figure 9). In the non-liquefied area near the glacier (sites $583 \mathrm{NAB}, 584 \mathrm{NAB}$, and 585NAB) shear-wave velocities in the upper $6 \mathrm{~m}$ are mostly above $190 \mathrm{~m} / \mathrm{s}$, whereas north of the edge of liquefaction triggering (sites $580 \mathrm{NAB}, 581 \mathrm{NAB}$ ) velocities fall below $160 \mathrm{~m} / \mathrm{s}$. The liquefied sites have velocities, normalized using effective stress, in the range of $157 \mathrm{~m} / \mathrm{s}-190 \mathrm{~m} / \mathrm{s}$ in the critical layer.

Conceptually, the abrupt transition of features $5 \mathrm{~km}$ south of the fault from no liquefaction to liquefaction, and the elongated $80-\mathrm{km}$ zone of liquefaction to the north can be explained by the attenuating seismic loads on either side of the fault rupture and the northward-decreasing soil capacity to resist liquefaction (Figure 10). South of the fault crossing, the load and resistance curves sharply intersect. Here, we expect the transition to be abrupt from areas of non-liquefaction to areas of moderate to severe liquefaction, consistent with the surface observations. On the other hand, north of the fault both the seismic load and the soil capacity to resist liquefaction decrease away from the fault. Liquefaction occurs when loads exceed resistance, and transitions into areas of liquefied deposits are expected to be gradual and to extend potentially far away from the source of the loads, again consistent with these observations. 


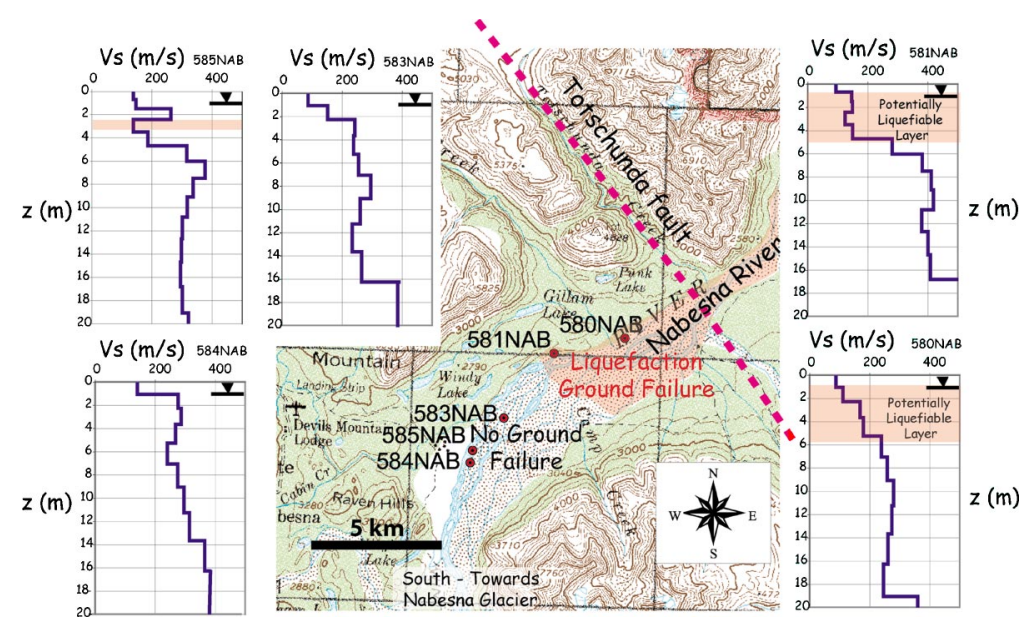

Figure 9. Mean grain size and shear wave velocity both fall down-stream (northward) from the Nabesna glacier. On the south side of the fault rupture, the shear wave profiles progressively decrease in velocity toward the fault. Low shear wave velocities in sand and gravel (red zone) indicate potentially liquefiable near-surface strata.
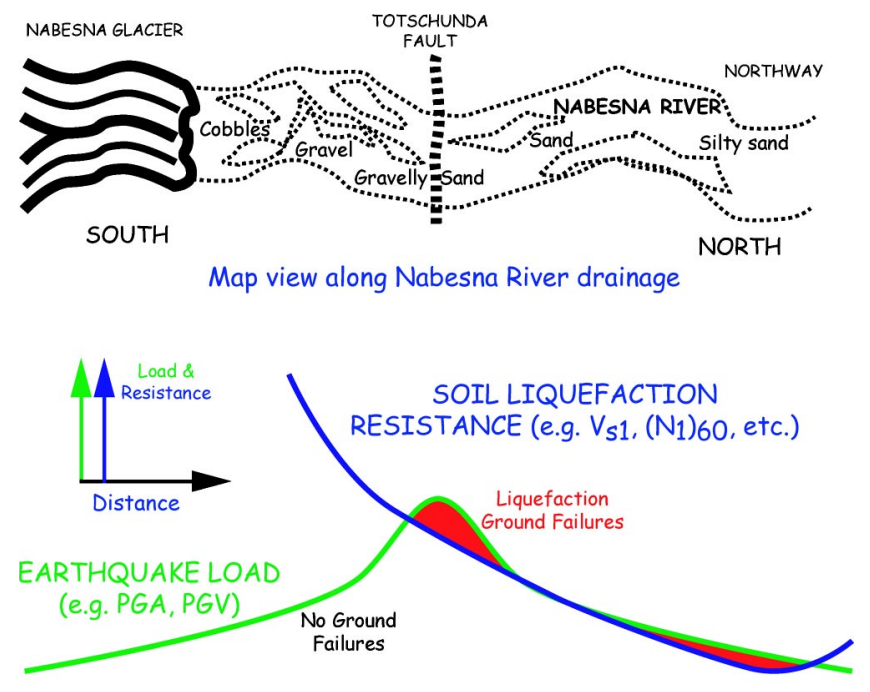

Earthquake load and soil capacity along Nabesna River drainage

Figure 10. Conceptual diagram of the relation between earthquake load and soil liquefaction resistance. On the south side of the fault, rising ground motion intensity intersects falling soil liquefaction resistance: the transition zone into liquefaction is abrupt. On the north side of the fault, ground motion intensity and liquefaction resistance both fall in tandem. Areas where load exceeds capacity result in liquefaction ground failures. 
The asymmetrical liquefaction patterns across the fault rupture zone are explained by the combination of the earthquake motion attenuation curve and the soil liquefaction resistance capacity curve. For a given geologic unit (e.g. young Holocene river deposits), attenuation of motion is dependent upon a function of depth of rupture and distance from the fault. Events with deep-rupture depths tend to flatten the attenuation curve in areas close to the fault zone, while lowering the amplitude of motion. For shallow events, or surface-rupturing events like the Denali fault earthquake, motion typically attenuates more rapidly with distance from the fault, often commencing close to the fault zone. For near-vertical strike-slip faults it is likely that the attenuation pattern of ground motion intensity will be symmetrical about the axis of the rupture zone (Boore et al. 1997).

The liquefaction resistance of the soil is due to the stress state and stratigraphy of the soil deposit (e.g., texture, degree of compaction and saturation, age, and the presence of drainage-impeding fines). Soils of the Nabesna River in the vicinity of the fault zone are young Holocene cohesionless deposits, with a water table within $0.5 \mathrm{~m}-1 \mathrm{~m}$ of the surface, and no fined-grain cap layer. The soils $5 \mathrm{~km}$ or more south of the fault are close to the Nabesna Glacier and are dominated by cobbles, gravel and gravely sand deposits. Within $5 \mathrm{~km}$ of the fault zone, on the south side, the deposits transition in texture to those commonly liquefied during shaking (Youd et al. 2001). The soil stays within this textural zone from near the fault crossing north to the confluence of the Tanana River. We infer this natural sorting process of Nabesna River deposits has led to a liquefaction resistance capacity profile that is asymmetrical about the axis of the fault rupture plane. Thus, the relation between the assumed symmetrical ground motion attenuation profile and the asymmetrical soil capacity profile controls the spatial distribution of liquefaction.

\section{DELTA RIVER DRAINAGE}

Liquefaction along the Delta River is more complex than along the Nabesna River. On the Delta River, numerous tributary glacial streams form cobble and gravel fans that introduce large volumes of new material into the main-stem deposits of the river. They are highly resistant to liquefaction under any loading scenario. The effect of these tributaries is to coarsen and poorly re-sort the main-stem material for downstream transport and deposition. Here, we describe the features along the Delta River from its headwaters to the confluence with the Tanana River.

Upstream of where runoff from the Canwell glacier enters the Delta River, we observed liquefaction features in the main stem of the Delta River, and in its side tributaries. By far, the most abundant and damaging liquefaction features were observed at Fielding Lake State Park on the Phelan Creek tributary of the Delta River. These include lateral spreads, severe fissuring, and submergence of the shoreline. Below the park, the deposits of the Delta River had localized sand boils and minor fissures in the vicinity of the fault crossing. Beyond the fault crossing zone, liquefaction was not observed on the river. 


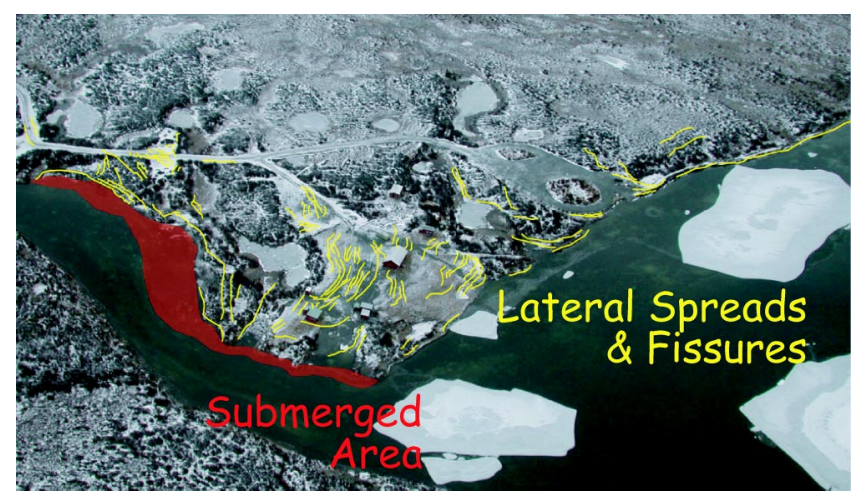

Figure 11. Oblique air photo of lateral spreading and fissures at Fielding Lake. The fissures are marked in yellow. A portion of the northern shoreline was laterally spread and submerged.

\section{Fielding Lake}

Fielding Lake is located on one of the headwater drainages of the Delta River, at Phelan Creek, south of the fault crossing, and within two kilometers of Isabel Pass, the drainage divide for the Alaska Range. Widespread liquefaction, lateral spreading, sand boils, and submerged ground were observed at Fielding Lake where the upper soil crust was not frozen at the time of the earthquake (Figure 11). Seen here were classic features associated with lateral spreading along a lakeshore, such as large fissures roughly parallel to the contours, and displacement of the ground towards lower areas. In areas of low-lying brush along the northeast end of the lake, at the exiting stream that drains to Phelan Creek, laterally spread and settled ground sank below lake level, submerging and drowning vegetation. Light wood-frame structures built on lateral-spreading ground were tilted and displaced down-slope, and an underground septic tank became buoyant, lifting a small out-house above the ground (Figures 12 and 13).

At Fielding Lake, we augured several holes to sample the liquefied zone and measured three SASW-based shear-wave velocity profiles, all with similar characteristics. The liquefiable soil layer at Fielding Lake is a low-plasticity, silty sand in the upper $3 \mathrm{~m}$, underlain by a stiffer gravelly sand. The shear-wave velocity of the critical layer was in the range of $111 \mathrm{~m} / \mathrm{s}-125 \mathrm{~m} / \mathrm{s}$, and is extremely low when compared with other documented sites that have liquefied during past earthquakes (Kayen et al. 2003) and accounts for the severity of ground displacements observed at the park (Figure 14).

\section{Delta River Near the Fault Crossing}

North of Fielding Lake and the confluence of Phelan Creek with the Delta River, localized sand boils and small fissures were observed in young Delta River deposits in the vicinity of Miller Creek, and near the pipeline's Regulator Gate Valve 91 (site RGV91), $1.5 \mathrm{~km}$ south of the fault. The valve was damaged when the pipeline support sank $75 \mathrm{~cm}$ into backfill consisting of poorly graded sandy material. The manual gatewheel for the valve sank below grade and could not be operated without excavation. The 


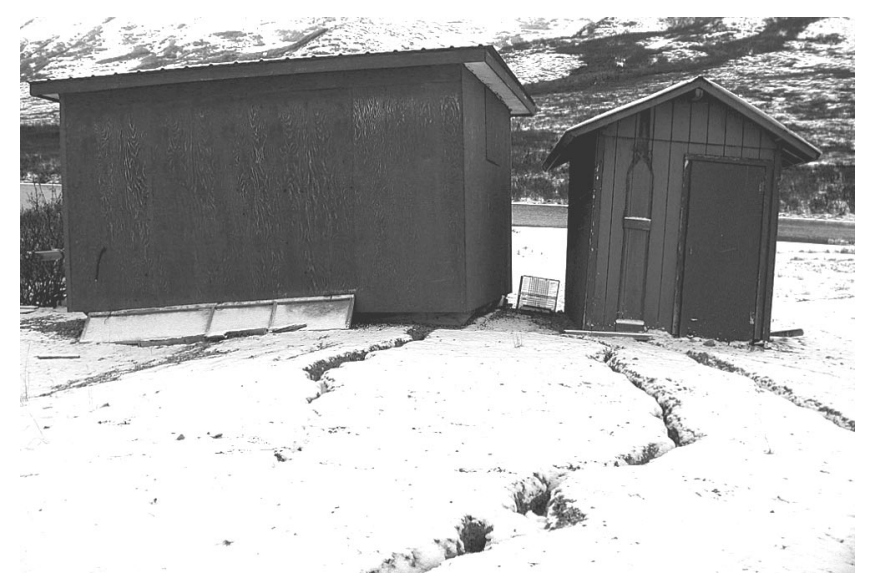

Figure 12. Laterally displaced ground deformed and tilted structures at Fielding Lake (SASW Site 599-FLD).

pipeline backfill at RGV91 and along a 1-km zone south of the fault liquefied, resulting in settlement, and ground fissures along the axis of the pipe.

North of the fault crossing, i.e. further upstream, where the Black Rapids Glacier and McGinnis Glacier discharge their sediment load into the Delta River, the texture of the alluvium becomes predominantly gravel and gravely sand. No liquefaction was observed on the Delta River deposits south of the confluence of these rivers.

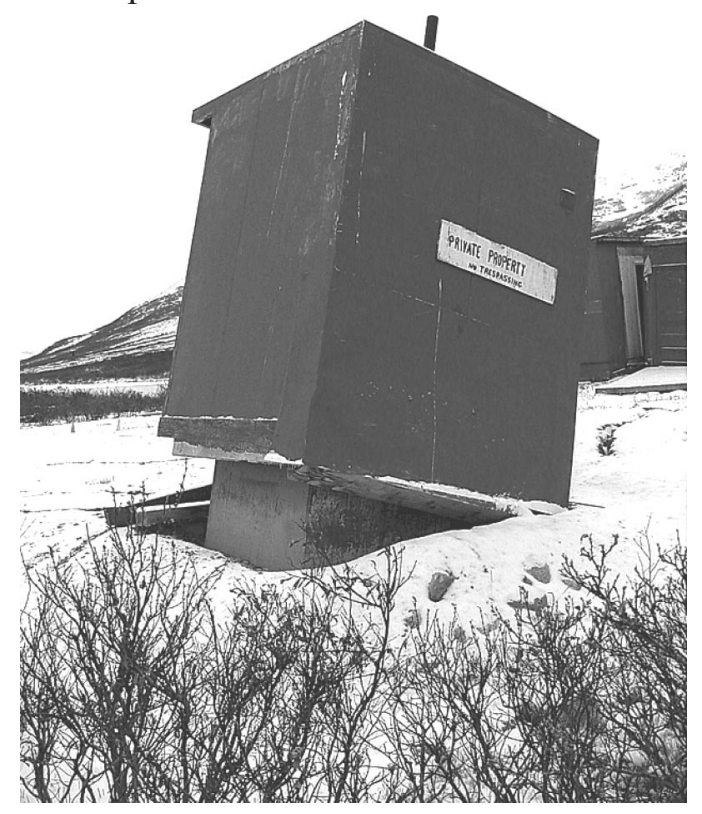

Figure 13. An underground septic tank at Fielding Lake became buoyant in liquefied soil lifting a small out house structure above the ground surface (SASW site 599-FLD). 

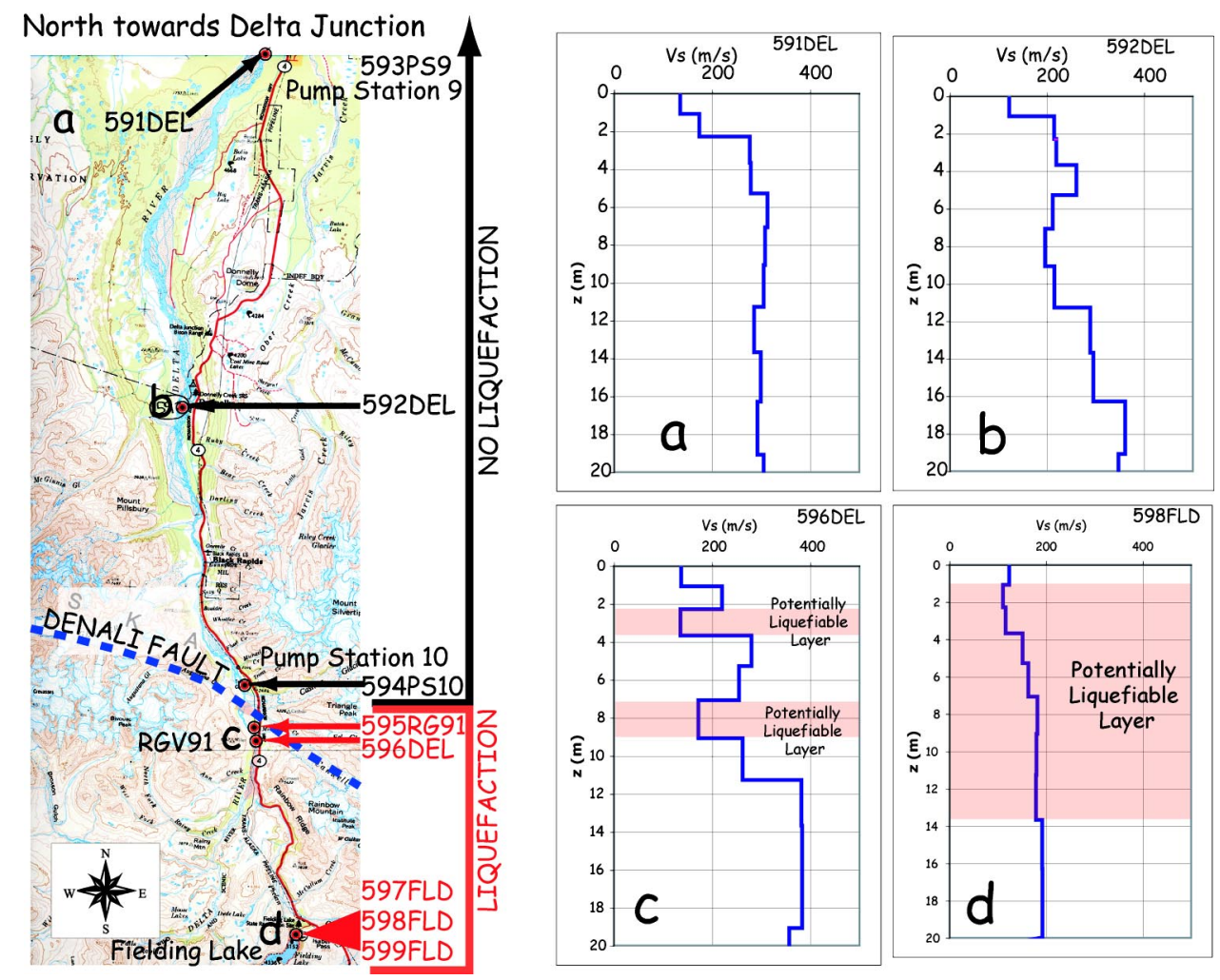

Figure 14. SASW-derived shear wave velocity profiles for four sites in the Delta River region of the central Alaska Range.

A conceptual profile of the relationship between earthquake motion loads and soil liquefaction resistance is presented in Figure 15. The geotechnical environment along the Delta River valley is more complex than along the Nabesna River valley because it has numerous side-entering glacial valleys bringing a significant load into the main-stem of the Delta River and altering the textural composition and liquefaction resistance. Liquefaction occurs at, and south of, the fault rupture upstream of glacial rivers that deposit cobble and gravel-rich poorly-sorted sediment into the Delta River.

\section{SUSITNA RIVER}

The final area where we conducted reconnaissance was along the western 100-km portion of the Denali fault rupture and the Susitna Glacier thrust fault. The Denali Highway was closed for the winter to traffic prior to the earthquake and could not be driven until the summer of 2003. However, helicopter reconnaissance of the Susitna Glacier fault area following the November event identified that liquefaction had occurred forward (south) of the thrust (P. Haeussler, personal communication). The Denali Highway runs east-west parallel and south of the central Alaskan Range from the town of Paxson to the town of Cantwell. The highway crosses and parallels several major glacially de- 

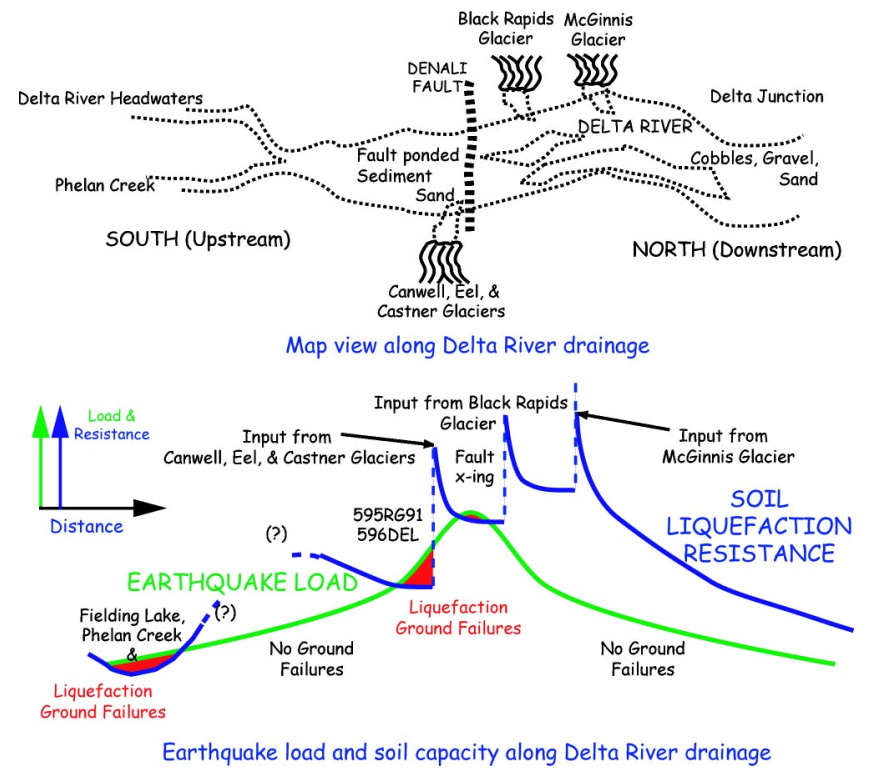

Figure 15. Conceptual diagram of the relation between earthquake load and soil liquefaction resistance capacity for the Delta River drainage. Areas where load exceeds capacity result in liquefaction ground failures. On the Delta River, the falling capacity is punctuated by abrupt inputs of poorly sorted material from side entering canyons. These inputs elevate the resistance capacity of the soil above loads imparted by the Denali fault event.

rived rivers, including the Delta River, which forms in headwater lakes approximately 25 $\mathrm{km}$ west of Paxson, the Maclaren River, the Susitna River, and the Nenana River.

With the exception of one embankment failure in the Tangle Lakes region near the headwaters of the Delta River, no ground failures were observed along the Denali Highway, though high water prevented viewing much of the river deposits. At Tangle Lakes, ground-cracking parallel to the road along a 10-m tall embankment was observed.

Airborne reconnaissance was used to investigate reports of liquefaction in the headwaters area of the West Fork and Susitna Rivers immediately downstream of their namesake glaciers (Figure 16). Severe liquefaction was observed over a widespread area that had dense networks of sand boils and lateral spread features. The liquefaction area was perhaps four square miles in size, south of the toe of the Susitna Glacier moraine.

Sand boils were densely located in this area with many located along linear fissures. Some sand boils left sizeable craters up to $15-\mathrm{cm}$ deep with ejecta fining away from the central crater (Figure 17). Liquefied deposits consisted of poorly graded coarse sands and well-graded sandy gravels. In some cases, the particle size of some of the ejecta was on the order of several centimeters in diameter, indicating that the severity of shaking during the event, and the rate of fluid expulsion from the liquefied layer to the surface were both high. 


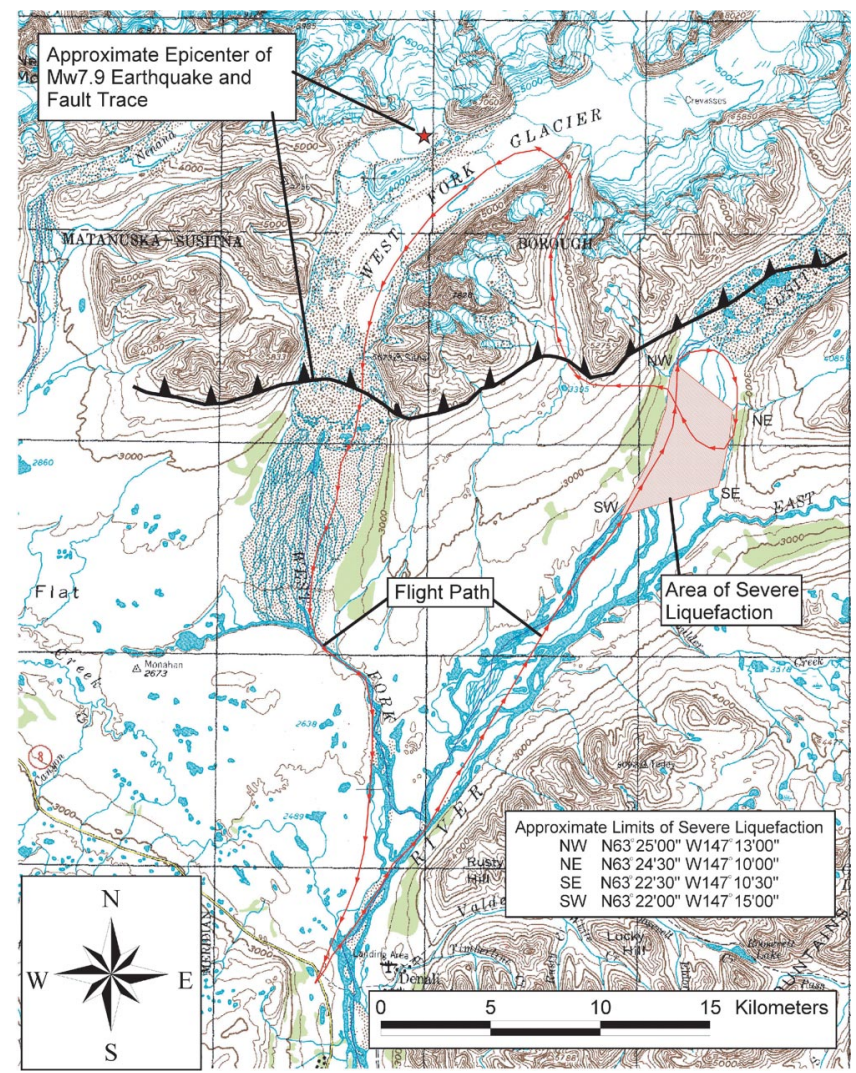

Figure 16. Air and surface reconnaissance of West Fork and Susitna glacier drainages identified a liquefaction field immediately south of the Susitna Glacier thrust fault near the toe of the Susitna Glacier.

\section{SHEAR-WAVE STRUCTURE OF TRANS-ALASKA PIPELINE PUMP STATION FACILITIES}

The ground motion of this M7.9 earthquake is poorly constrained due to the limited number of strong-motion instrumentation sites in central Alaska. There are three strong motion records from the Alyeska Pump Stations 9, 10, and 11. The record from Pump Station 10 is of greatest interest as it is located just $3 \mathrm{~km}$ from where the Denali fault ruptured with offsets over $5 \mathrm{~m}$ horizontally and $1 \mathrm{~m}$ vertically (see Ellsworth et al. 2004). The other two stations recorded motions at $56 \mathrm{~km}$ (PS9) and $125 \mathrm{~km}$ (PS11) distances. The instruments at the pump station facilities are part of the accelerometer network operated by Alyeska to provide seismic alarms for pipeline operations control. The instrument enclosures for the three stations are on Holocene gravels on level ground, 50 $\mathrm{m}-100 \mathrm{~m}$ from the nearest buildings. The accelerometers are mounted on concrete slabs on grade. Here, we present shear-wave velocity profiles for the three pump stations.

Pump Station 9 (site PS9) is an active pumping facility immediately south of the town of Delta Junction. The fault is approximately $56 \mathrm{~km}-70 \mathrm{~km}$ to the south. We per- 


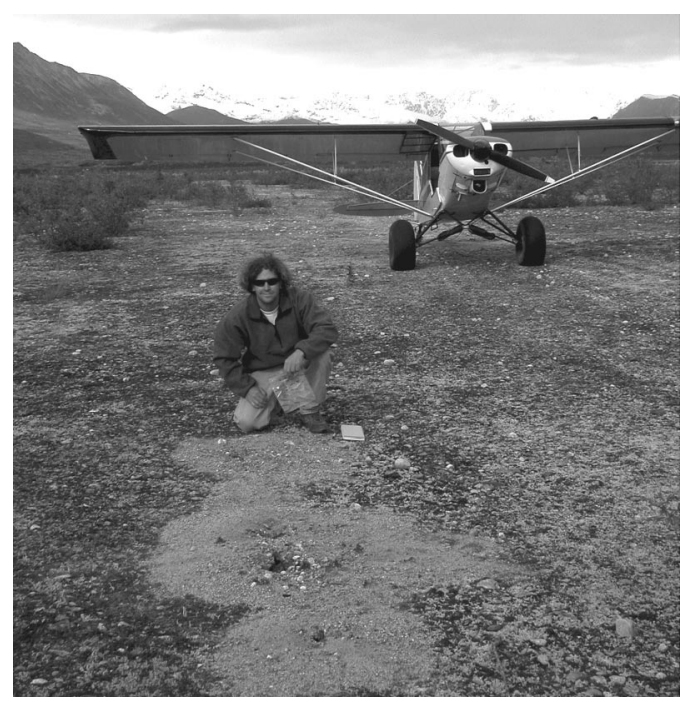

Figure 17. Sand boils in the upper Susitna River valley south of the Susitna Glacier terminal moraine.

formed SASW tests with array separations ranging from $2 \mathrm{~m}$ to $200 \mathrm{~m}$, and conducted passive signal microtremor tests, recording the surface-wave vibrations of the jet-turbine building. Phase velocities for PS9 were computed by merging the cross-power spectral data and the array dimension (the distance between sensors). From the phase velocities, a shear-wave velocity profile was computed by inversion, which has a least squares bestfit theoretical dispersion curve compared with the field-data dispersion curve. The soil at PS9 is stiff gravely ground moraine that is graded and gravel-covered at the surface, and this site has excellent surface-wave transmission. Our testing measured surface wavelengths of $340 \mathrm{~m}(1100 \mathrm{ft})$ from which we inverted a 140-m profile. At PS9 we estimate the average $30-\mathrm{m}$ shear-wave velocity to be $376 \mathrm{~m} / \mathrm{s}$ (Figure 18). This gives the site an IBC2003 site classification C (International Code Council 2002), near the C/D boundary.

Pump Station 10 (site PS10) is an inactive facility approximately $3 \mathrm{~km}$ north of the rupture. It was taken off-line six years before the earthquake. At the time of the event, the facility piping, vessels and storage tanks were empty, and the station did not sustain any structural damage (Hall et al. 2003). Boreholes to a depth of $30 \mathrm{~m}$ show the deposits to be coarse, non-cohesive soil ranging from gravely sand to silty gravel and up to boulders (National Soil Service 1971). The average blow count of the upper $30 \mathrm{~m}$ is about 50. As with PS9, the surface-wave transmission at PS10 was excellent and we were able to capture wavelengths of up to $720 \mathrm{~m}(2300 \mathrm{ft})$. Indeed, data collection was so successful at this site that only the physical limitations of pump station dimension and cable length prevented collection of longer-wavelength data. The average shear-wave velocity for PS10 in the upper $30 \mathrm{~m}$ is $316 \mathrm{~m} / \mathrm{s}$, and shear-wave velocity exceeds $600 \mathrm{~m} / \mathrm{s}$ at a depth of about $115 \mathrm{~m}$ (Figure 18). Thus the soil is classified as IBC2003 site classification D. 


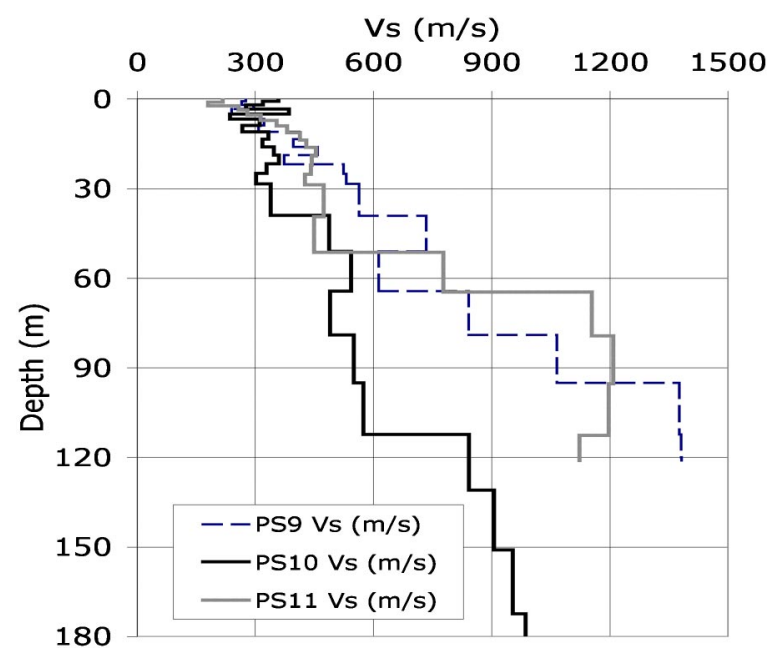

Figure 18. Shear wave velocity structure of Trans-Alaska Pipeline Pump Stations PS9, PS10 and PS11. Velocity profiles were inverted from active and passive array surface wave dispersion data.

The pipeline at site PS11 is located on a graded and terraced platform immediately south of the town of Glennallen. Here, the pipeline drops off a steep, incised, hill slope of ground moraine onto a flat alluvial pad prepared for the station. The fault is located approximately $125 \mathrm{~km}-150 \mathrm{~km}$ to the north. At PS11, we measured surface-wave wavelengths up to $300 \mathrm{~m}$ (about 1,000 ft). The $30-\mathrm{m}$ average shear-wave velocity for Pump Station 11 is $362 \mathrm{~m} / \mathrm{s}$, giving the site an IBC2003 site classification of $\mathrm{C}$ at C/D boundary (Figure 18).

\section{DISCUSSION AND CONCLUSIONS}

Based on the spatial distribution of liquefaction, it appears the rupture energy and more intense ground motions were focused toward the eastern end of the Denali fault and Totschunda fault. The liquefaction features most distant from the fault were in the Northway area, a region of lowlands and bogs, where ground failures were ubiquitous. The Northway area is $130-180 \mathrm{~km}$ from the area of maximum displacement on the Denali fault and about $80 \mathrm{~km}$ from the closest point on the Totschunda fault. Liquefaction features on the western end of the fault were sparse with the exception of features immediately south of the Susitna Glacier thrust fault, and isolated fissures and lateral spreads on bars of the Tanana River near Fairbanks.

The distribution of liquefaction effects triggered by the Denali fault earthquake was unusual in many aspects. The large areal distribution of liquefaction features compared to the limited zone of landslides (Harp et al. 2003) suggests that minimum shaking levels and duration requirements for liquefaction were more extensive than those needed to trigger rock falls and rock slides. The higher concentrations and severity of liquefaction effects to the east, in the area of the third subevent of the earthquake, suggest that ground-motion durations or amplitudes were greater in that area as a result of directivity 


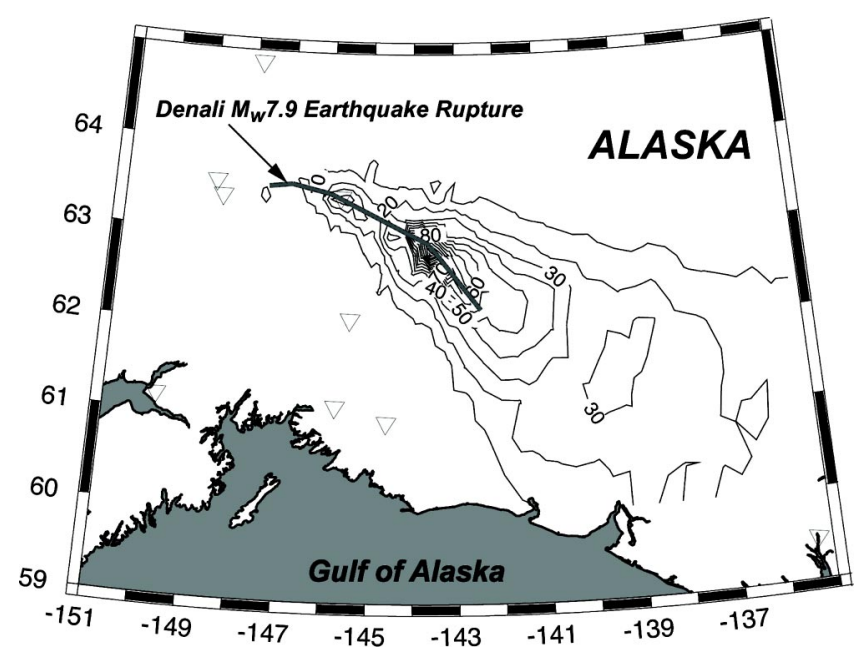

Figure 19. Map showing the 5-segment fault model (bold), and locations of seismic stations (triangles) used to determine a kinematic rupture model (e.g. Dreger et al., 2004). Peak ground velocity (PGV) contours derived from the kinematic source model are computed following the method of Dreger and Kaverina (2000). The contour interval is $10 \mathrm{~cm} / \mathrm{s}$ (thin lines). The eastward expanding cone of PGV contours show the effect of unilateral rupture.

effects and the greater fault slip there. Though strong-motion records are sparse, seismograms derived from kinematic source models of the earthquake rupture process support the field observations of more concentrated and severe liquefaction features in the eastern portion of the damage area. These seismograms are generated from the inversion of regional seismic waveform data and GPS deformation data. The kinematic source model is described in detail in Dreger et al. (2004) and Oglesby et al. (2004). Peak ground velocities (PGV) in the geotechnical damage region were calculated using the method described in Dreger and Kaverina (2000) and are plotted in Figure 19. The area of high ground velocity, greater than $10 \mathrm{~cm} / \mathrm{s}$, extends several hundred kilometers to the east and approximately $100 \mathrm{~km}$ northward and southward of the eastern-most extent of the ruptured Totschunda fault. The PGV contours showing this expanding area of strong motion toward the east are approximately symmetric about the fault. The seismic waveform data for the inversion is low-pass filtered at $0.5 \mathrm{~Hz}$, and consequently the PGV is band limited.

The geographic pattern of liquefaction provides a physical record of shaking levels against which to test conceptual models designed to predict the geographic variation in shaking obtained from the analysis of distant seismic records. Kinematic rupture modeling supports the qualitative observation of directivity toward the east. The areas that may provide the best quantitative record of loads associated with earthquake motion and capacities associated with soil liquefaction resistance are the two river systems crossing the fault rupture zone, the Nabesna River and the Delta River. The Nabesna River, with a main-stem emanating from its namesake glacier and with smaller streams entering from the side, provides us with a simple setting to contrast loads and capacities. Here, 
we find shear-wave velocities fall steadily away from the glacier in cohesionless saturated sediments in the upper $5 \mathrm{~m}$ of soil. The asymmetrical liquefaction resistance pattern, measured by the northward-falling shear-wave velocities, interacts with an apparently fault-symmetrical seismic load, resulting in a northerly skewed liquefaction field. On the Delta River, energetic tributary streams, entering north and south of the fault zone, load the main stem with coarse material. Here, the glacial-river bedload of the side-entering streams significantly alter the properties of the Delta River, increasing the liquefaction resistance capacity of the deposits. The resulting intersection of assumed symmetrical seismic loads and abruptly altering liquefaction resistance capacities results in localized liquefaction zones south of, but close to, the fault zone.

The ground motion records of this M7.9 earthquake are few owing to a dearth of permanently stationed strong-motion sites in the central Alaska region. Alyeska obtained three valuable records of this event at Pump Stations 9, 10, and 11. We investigated the site characteristics of these stations using SASW techniques to profile the shear-wave velocity structure. Surface wave transmission at the three sites is excellent and allows us to profile the shear-wave velocity structure to depths between $140 \mathrm{~m}$ and $200 \mathrm{~m}$. The average 30-m velocities at sites PS9, PS10, and PS11 are $376 \mathrm{~m} / \mathrm{s}$ (IBC2003 site classification C, near C/D boundary), $316 \mathrm{~m} / \mathrm{s}$ (IBC2003 site classification D), and $362 \mathrm{~m} / \mathrm{s}$ (IBC2003 site classification C, near C/D boundary), respectively. With only one close-in strong-motion record for this event, and few records within 200 kilometers, there is insufficient strong-motion instrumentation available to identify local areas of amplified ground motion. Regions of pervasive liquefaction (e.g. the eastern Tanana River and Nabesna River) may serve as a proxy for areas of strong ground motion and may provide the best physical evidence of the motion in river basins and of the directivity associated with the unidirectional fault rupture for this sparsely recorded event.

\section{ACKNOWLEDGMENTS}

We wish to thank NSF, the USGS, the Pacific Earthquake Engineering Research Center, and the Alyeska Pipeline Service Company for their support of the 2002 reconnaissance and 2003 geotechnical investigation. The reconnaissance was funded in part by NSF grant number CMS: 0314499. Woody Savage of the USGS was instrumental in arranging site visits to the Alyeska pump stations. The Alaska Department of Transportation and Public Facilities, Statewide GIS Mapping Section, provided GIS highway data. David Schwartz and Peter Haeussler are thanked for coordinating their fault investigation field efforts with our SASW investigation of the Nabesna River valley. The manuscript was greatly improved by the reviews of Peter Haeussler and Brad Carkin.

\section{APPENDIX 1}

Soil classification results from geotechnical laboratory testing are included in Table A1 for 35 samples obtained during the reconnaissance.

\section{APPENDIX 2}

Table A2 shows GPS locations of observed damage and test sites. 
Table A1. Soil classification test results for liquefied evaluation sites investigated by the spectral analysis of surface waves (SASW) or observed (at the Susitna River sites).

\begin{tabular}{|c|c|c|c|c|c|c|c|c|c|}
\hline Area & Site & Depth (m) & Location & Liquefied? & SASW & $\mathrm{D} 50^{1}(\mathrm{~mm})$ & $\mathrm{CU}^{2}$ & $\%$ Fines & $\begin{array}{c}\text { USCS }^{3} \\
\text { Classification }\end{array}$ \\
\hline \multirow[t]{7}{*}{ Slana River } & 578SLA & 0.6 & embankment fill & $\mathrm{Y}$ & $\mathrm{Y}$ & 0.7 & 37.5 & 9.0 & $\mathrm{SP}$ \\
\hline & 578SLA & 1.2 & embankment fill & $\mathrm{Y}$ & $\mathrm{Y}$ & 4 & 22.2 & 3.1 & $\mathrm{SP}$ \\
\hline & 579SLA & 0 & surficial sand boil & $\mathrm{Y}$ & $\mathrm{Y}$ & 0.25 & 3.1 & 6.9 & $\mathrm{SP}$ \\
\hline & 579SLA-(rk) & 0 & surficial sand boil & $\mathrm{Y}$ & $\mathrm{Y}$ & 0.095 & 2.4 & 31.6 & SM \\
\hline & 579SLA & 1.2 & auger sample & $\mathrm{Y}$ & $\mathrm{Y}$ & 0.035 & 15.0 & 86.2 & ML \\
\hline & 579SLA & 2.4 & auger sample & $\mathrm{Y}$ & $\mathrm{Y}$ & 0.2 & 2.6 & 7.5 & $\mathrm{SP}$ \\
\hline & & & & & $\mathrm{Y}$ & & & & \\
\hline \multirow[t]{8}{*}{ Nabesna River } & $580 \mathrm{NAB}$ & 0 & surficial sand boil in bar & $\mathrm{Y}$ & $\mathrm{Y}$ & 0.5 & 7.5 & 5.3 & SW \\
\hline & $580 \mathrm{NAB}$ & 0.3 & auger sample & $\mathrm{Y}$ & $\mathrm{Y}$ & 5.3 & 27.5 & 1.2 & GP \\
\hline & $582 \mathrm{NWY}$ & 0 & surficial sand boil & $\mathrm{Y}$ & $\mathrm{Y}$ & 0.25 & 2.3 & 5.6 & $\mathrm{SP}$ \\
\hline & $582 \mathrm{NWY}$ & 1.5 & auger sample & $\mathrm{Y}$ & $\mathrm{Y}$ & 0.26 & 1.9 & 2.0 & $\mathrm{SP}$ \\
\hline & $582 \mathrm{NWY}$ & 2.7 & auger sample & $\mathrm{Y}$ & $\mathrm{Y}$ & 0.26 & 1.9 & 3.3 & $\mathrm{SP}$ \\
\hline & $583 \mathrm{NAB}$ & 0.3 & river bar & $\mathrm{N}$ & $\mathrm{Y}$ & 9.5 & 21.0 & 0.1 & GW \\
\hline & $584 \mathrm{NAB}$ & 0.3 & river bar & $\mathrm{N}$ & $\mathrm{Y}$ & 7.1 & 25.0 & 0.4 & GW \\
\hline & $585 \mathrm{NAB}$ & 0.3 & river bar & $\mathrm{N}$ & $\mathrm{Y}$ & 9.6 & 35.0 & 1.8 & GP \\
\hline Tok River & 589TOK & 0 & surficial sand boil in bar & $\mathrm{Y}$ & $\mathrm{Y}$ & 0.22 & 2.9 & 8.3 & SP \\
\hline Gerstle River & 590GER & 1.8 & quarry pit wall in bed & $\mathrm{N}$ & $\mathrm{Y}$ & 8.9 & 34.0 & 0.8 & GP \\
\hline \multirow[t]{6}{*}{ Delta River } & 591DEL & 0 & river bar & $\mathrm{N}$ & $\mathrm{Y}$ & 0.09 & 4.8 & 37.4 & SM \\
\hline & 592DEL & 0 & river bar & $\mathrm{N}$ & $\mathrm{Y}$ & 6.3 & 22.5 & 0.5 & GP \\
\hline & 595R91 & 0 & surficial sand boil & $\mathrm{Y}$ & $\mathrm{Y}$ & 0.3 & 3.7 & 5.0 & $\mathrm{SP}$ \\
\hline & 595R91 & 0 & articial fill over pipeline & $\mathrm{Y}$ & $\mathrm{Y}$ & 0.47 & 5.0 & 5.1 & $\mathrm{SP}$ \\
\hline & 596DEL & 0 & surficial sand boil in bar & $\mathrm{Y}$ & $\mathrm{Y}$ & 0.13 & 2.0 & 17.4 & SM \\
\hline & 596DEL & 0.3 & auger sample & $\mathrm{Y}$ & $\mathrm{Y}$ & 0.18 & 2.5 & 8.8 & $\mathrm{SP}$ \\
\hline
\end{tabular}


Table A1. (cont.). Soil classification test results for liquefied evaluation sites investigated by the spectral analysis of surface waves (SASW) or observed (at the Susitna River sites).

\begin{tabular}{|c|c|c|c|c|c|c|c|c|c|}
\hline Area & Site & Depth (m) & Location & Liquefied? & SASW & $\mathrm{D} 50^{1}(\mathrm{~mm})$ & $\mathrm{CU}^{2}$ & $\%$ Fines & $\begin{array}{c}\text { USCS }^{3} \\
\text { Classification }\end{array}$ \\
\hline \multirow{9}{*}{ Fielding Lake } & 597FLD & 0.3 & surficial sand boil & $\mathrm{Y}$ & Y & 0.12 & 2.2 & 19.2 & SM \\
\hline & 597FLD & 0.9 & auger sample & $\mathrm{Y}$ & $\mathrm{Y}$ & 0.0075 & 100.0 & 99.5 & ML \\
\hline & 597FLD & 1.5 & auger sample & $\mathrm{Y}$ & $\mathrm{Y}$ & 0.03 & 17.7 & 85.9 & ML \\
\hline & 597FLD & 1.8 & auger sample & Y & $\mathrm{Y}$ & 0.085 & 120.0 & 48.7 & SM \\
\hline & 597FLD & 2.1 & auger sample & $\mathrm{Y}$ & $\mathrm{Y}$ & 0.11 & 20.0 & 43.7 & SM \\
\hline & 598FLD & 0 & surficial sand boil & $\mathrm{Y}$ & $\mathrm{Y}$ & 0.3 & 4.8 & 8.4 & SP \\
\hline & 598FLD & 0.8 & auger sample & $\mathrm{Y}$ & $\mathrm{Y}$ & 0.82 & 8.3 & 4.3 & SP \\
\hline & 599FLD & 0 & surficial lateral spread & $\mathrm{Y}$ & $\mathrm{Y}$ & 0.036 & 6.3 & 93.1 & ML \\
\hline & 599FLD & 0.9 & auger sample & $\mathrm{Y}$ & $\mathrm{Y}$ & 0.024 & 7.2 & 81.6 & ML \\
\hline \multirow[t]{4}{*}{ Susitna River } & SUSITNA-1 & 0 & surficial sand boil in bar & $\mathrm{Y}$ & $\mathrm{N}$ & 0.75 & 4.8 & 1.8 & SP \\
\hline & SUSITNA-2 & 0 & surficial sand boil in bar & $\mathrm{Y}$ & $\mathrm{N}$ & 0.66 & 4.2 & 1.5 & SP \\
\hline & SUSITNA-3 & 0 & surficial sand boil in bar & $\mathrm{Y}$ & $\mathrm{N}$ & 0.49 & 5.4 & 2.8 & SP \\
\hline & SUSITNA-4 & 0 & surficial sand boil in bar & $\mathrm{Y}$ & $\mathrm{N}$ & 10 & 25.7 & 0.7 & GW \\
\hline
\end{tabular}

D50: mean grain size diameter

${ }^{2} \mathrm{CU}$ : Coefficient of uniformity

${ }^{3}$ USCS: Unified Soil Classification System. See, for example, http://www.usace.army.mil/publications/armytm/tm5-850-1/c-4.pdf 
Table A2. Coordinates of observed ground damage features.

\begin{tabular}{|c|c|c|c|c|c|c|c|}
\hline LOCATION & Observation $^{1}$ & Observ. Type & Waypoint name & Lat. $\mathrm{N}\left({ }^{\circ}\right)$ & Lat. $N\left({ }^{\prime}\right)$ & Long. W $\left({ }^{\circ}\right)$ & Long W. $\left({ }^{\prime}\right)$ \\
\hline Northway road embankment & $\mathrm{L}, \mathrm{LS}$, bent culverts & Ground & WPT $261^{*}$ & 62 & 59.062236 & 141 & 49.2095952 \\
\hline Northway Airport, NE & $\mathrm{L}, \mathrm{lm}$ sunken tarmac & Ground & WPT $268^{*}$ & 62 & 57.710391 & 141 & 55.1789718 \\
\hline Northway Airport, NE & $\mathrm{L}, 20 \mathrm{~cm}$ fissures & Ground & WPT $267^{*}$ & 62 & 57.6759732 & 141 & 55.6045836 \\
\hline Northway Airport, East & $\mathrm{L}, 8-13 \mathrm{~cm}$ fissures & Ground & WPT $265^{*}$ & 62 & 57.6253284 & 141 & 55.9604316 \\
\hline Northway Weather Station & $\mathrm{L}$ & SASW & $587 \mathrm{NOR}$ & 62 & 57.763 & 141 & 56.114 \\
\hline $\begin{array}{l}\text { Northway, Tilted High } \\
\text { Voltage House }\end{array}$ & $\mathrm{L}$ & SASW & $586 \mathrm{NOR}$ & 62 & 57.69 & 141 & 56.25 \\
\hline Northway Baseball Field & $\mathrm{L}$ & SASW & $582 \mathrm{NOR}$ & 62 & 57.68 & 141 & 56.392 \\
\hline $\begin{array}{l}\text { Northway, Tilted High } \\
\text { Voltage House }\end{array}$ & $\mathrm{L}$, titled structures & Ground & WPT $269^{*}$ & 62 & 57.6762186 & 141 & 56.4103788 \\
\hline Northway Airport, S. end & $\mathrm{L}, 8-10 \mathrm{~cm}$ fissures & Ground & WPT $263^{*}$ & 62 & 57.588696 & 141 & 56.5715382 \\
\hline Northway Airport, S. end & $\mathrm{L}, 5 \mathrm{~cm}$ fissures & Ground & WPT $262^{*}$ & 62 & 57.5488668 & 141 & 56.7472986 \\
\hline Northway & L, LS, tilted power poles & Ground & WPT $272^{*}$ & 62 & 58.9244202 & 141 & 57.1988688 \\
\hline Tanana River, Teltin2 & $\mathrm{L}, 3.8-3.9 \mathrm{~m} \mathrm{LS}$ & Ground & TETL2STR & 63 & 18.734856 & 142 & 38.7081552 \\
\hline Tanana River, Teltin 1 & $\mathrm{~L}, 4.2-4.4 \mathrm{~m} \mathrm{LS}$ & Ground & TETLINI & 63 & 18.613407 & 142 & 38.79198 \\
\hline Tanana River, Teltin 2 & $\mathrm{~L}, 3.8-3.9 \mathrm{~m} \mathrm{LS}$ & Ground & TETL2END & 63 & 18.7511298 & 142 & 38.826591 \\
\hline Tanana River at Tetlin Bridge & $\mathrm{L}$ & SASW & 588TET & 63 & 19.055 & 142 & 38.827 \\
\hline Tanana River, Teltin 1 & $\mathrm{~L}, 4.2-4.4 \mathrm{~m} \mathrm{LS}$ & Ground & TETLSTRT & 63 & 18.4404492 & 142 & 38.8736412 \\
\hline Tanana River, Teltin1 & $\mathrm{L}, 4.2-4.4 \mathrm{~m} \mathrm{LS}$ & Ground & TETL-END & 63 & 18.5502504 & 142 & 39.1332258 \\
\hline Nabesna River & $\mathrm{L}$ & SASW & $580 \mathrm{NAB}$ & 62 & 25.868 & 142 & 44.748 \\
\hline Nabesna River & $\mathrm{L}$ & SASW & $581 \mathrm{NAB}$ & 62 & 25.518 & 142 & 47.497 \\
\hline Nabesna River & NL & SASW & $583 \mathrm{NAB}$ & 62 & 24.173 & 142 & 50.114 \\
\hline Nabesna River & NL & SASW & $585 \mathrm{NAB}$ & 62 & 23.481 & 142 & 51.464 \\
\hline Nabesna River & NL & SASW & 584NAB & 62 & 23.225 & 142 & 51.554 \\
\hline Tok River & $\mathrm{L}, \mathrm{LS}$ & AIR & WPT $235^{*}$ & 63 & 8.8158078 & 143 & 12.502896 \\
\hline Tok River & $\mathrm{L}, \mathrm{LS}$ & AIR & WPT $237^{*}$ & 63 & 7.50816 & 143 & 15.5503176 \\
\hline Tok River, Point bar & $\mathrm{L}, \mathrm{LS}$ & AIR & WPT $242^{*}$ & 63 & 6.8252322 & 143 & 16.9931784 \\
\hline Tok River & $\mathrm{L}, \mathrm{LS}$ & AIR & WPT $238^{*}$ & 63 & 5.829336 & 143 & 18.6285648 \\
\hline Tok River & $\mathrm{L}, \mathrm{LS}$ & AIR & WPT $231^{*}$ & 63 & 5.5638144 & 143 & 20.3418264 \\
\hline Tok River & $\mathrm{L}, \mathrm{LS}$ & AIR & WPT $232^{*}$ & 63 & 5.5638144 & 143 & 20.3418264 \\
\hline
\end{tabular}


Table A2. (cont.). Coordinates of observed ground damage features.

\begin{tabular}{|c|c|c|c|c|c|c|c|}
\hline LOCATION & Observation $^{1}$ & Observ. Type & Waypoint name & Lat. $\mathrm{N}\left({ }^{\circ}\right)$ & Lat. N (') & Long. W $\left({ }^{\circ}\right)$ & Lang W. (') \\
\hline Tok River & $\mathrm{L}, \mathrm{LS}$ & AIR & WPT $240^{*}$ & 62 & 57.790533 & 143 & 20.6992968 \\
\hline Little Tok River & L & SASW & 589TOK & 62 & 57.741 & 143 & 20.956 \\
\hline Little Tok_Lateral Spread & $\mathrm{L}$ & Ground & TOK-LS & 62 & 57.778 & 143 & 20.983 \\
\hline Rock Lake & Shattered ice & Ground & WPT $285^{*}$ & 62 & 33.8440968 & 143 & 24.932157 \\
\hline Tanana River & $\mathrm{L}, \mathrm{LS}$ & AIR & WPT $243^{*}$ & 63 & 22.2090504 & 143 & 27.0385824 \\
\hline Pond nr. Caribou Creek & Shattered ice (seiche) & Ground & WPT $284^{*}$ & 62 & 34.605672 & 143 & 32.158899 \\
\hline Slana River native ground & $\mathrm{L}$ & SASW & 579SLANA & 62 & 52.061 & 143 & 40.1 \\
\hline Slana River Enbankment & $\mathrm{L}$ & SASW & 578SLANA & 62 & 51.594 & 143 & 40.903 \\
\hline Slana Creek, Copper River & $\mathrm{L}, \mathrm{LS}$ & Ground & WPT $282^{*}$ & 62 & 42.2854056 & 143 & 56.7951516 \\
\hline Tanana River & $\mathrm{L}, \mathrm{LS}$ & AIR & WPT $259^{*}$ & 63 & 40.864509 & 143 & 57.6853122 \\
\hline Tanana River & $\mathrm{L}, \mathrm{LS}$ & AIR & WPT $245^{*}$ & 63 & 42.1568796 & 144 & 29.4049944 \\
\hline Tanana River & $\mathrm{L}, \mathrm{LS}$ & AIR & WPT $246^{*}$ & 63 & 42.1568796 & 144 & 29.4049944 \\
\hline Johnson River & NL & AIR & WPT $256^{*}$ & 63 & 42.4843698 & 144 & 43.4788356 \\
\hline Johnson River & NL & AIR & WPT $253^{*}$ & 63 & 50.6821278 & 144 & 46.1114616 \\
\hline $\begin{array}{l}\text { Gerstle River- } \\
\text { East Bank }\end{array}$ & NL & Ground & LGERSTLENL & 63 & 47.269 & 144 & 47.462 \\
\hline Johnson River & NL & AIR & WPT $255^{*}$ & 63 & 32.6492574 & 144 & 47.9934534 \\
\hline Gerstle River & NL & SASW & 590GER & 63 & 49.023 & 144 & 55.31 \\
\hline $\begin{array}{l}\text { TAP Pump Station } \\
11 \text { SASW Site }\end{array}$ & $\mathrm{L}$ & SASW & 600PS11-SASW & 62 & 5.263 & 145 & 28.738 \\
\hline $\begin{array}{l}\text { Fielding Lake State } \\
\text { Rec. Area SASW } \\
\text { site } 598\end{array}$ & $\mathrm{~L}$ & SASW & 598FLD & 63 & 11.676 & 145 & 38.789 \\
\hline $\begin{array}{l}\text { Fielding Lake State } \\
\text { Rec. Area SASW } \\
\text { site } 597\end{array}$ & $\mathrm{~L}$ & SASW & 597FLD & 63 & 11.585 & 145 & 38.798 \\
\hline $\begin{array}{l}\text { Fielding Lake State } \\
\text { Rec. Area SASW } \\
\text { site } 599\end{array}$ & $\mathrm{~L}$ & SASW & 599FLD & 63 & 11.565 & 145 & 38.835 \\
\hline $\begin{array}{l}\text { TAP Regulator } \\
\text { Gate Valve RGV91 }\end{array}$ & $\mathrm{L}$ & SASW & 595RGV91 & 63 & 21.376 & 145 & 43.664 \\
\hline
\end{tabular}


Table A2. (cont.). Coordinates of observed ground damage features.

\begin{tabular}{|c|c|c|c|c|c|c|c|}
\hline LOCATION & Observation $^{1}$ & Observ. Type & Waypoint name & Lat. $\mathrm{N}\left({ }^{\circ}\right)$ & Lat. $\mathrm{N}\left({ }^{\prime}\right)$ & Long. W $\left({ }^{\circ}\right)$ & Lang W. $\left({ }^{\prime}\right)$ \\
\hline Delta River near RV91 & $\mathrm{L}$ & SASW & 596DEL & 63 & 20.873 & 145 & 43.836 \\
\hline $\begin{array}{l}\text { TAP Pump Station } 10 \\
\text { seismometer }\end{array}$ & NL & SASW & 594PS10-SEIS & 63 & 25.443 & 145 & 45.782 \\
\hline $\begin{array}{l}\text { TAP Pump Station } 10 \\
\text { SASW site }\end{array}$ & NL & SASW & 594PS10-SASW & 63 & 25.411 & 145 & 45.86 \\
\hline $\begin{array}{l}\text { TAP Pump Station } 9 \\
\text { seismometer }\end{array}$ & NL & SASW & 593PS9-SEIS & 63 & 55.815 & 145 & 45.96 \\
\hline $\begin{array}{l}\text { TAP Pump Station } 9 \\
\text { SASW site }\end{array}$ & NL & SASW & 593PS9-SASW & 63 & 55.808 & 145 & 46.02 \\
\hline $\begin{array}{l}\text { Delta River at } \\
\text { Delta Junction }\end{array}$ & NL & SASW & 591DEL & 64 & 8.443 & 145 & 50.131 \\
\hline $\begin{array}{l}\text { Delta River near } \\
\text { Donnelly Dome }\end{array}$ & NL & SASW & 592DEL & 63 & 39.797 & 145 & 53.512 \\
\hline Tanana River & NL & AIR & WPT $249^{*}$ & 63 & 45.485856 & 145 & 58.614132 \\
\hline $\begin{array}{l}\text { Tanana River, } \\
\text { Fairbanks }\end{array}$ & $\mathrm{L}, \mathrm{LS}$ & AIR & WPT $251^{*}$ & 64 & 20.0472324 & 146 & 56.396703 \\
\hline $\begin{array}{l}\text { Susitna River-center } \\
\text { of Liq zone }\end{array}$ & $\mathrm{L}$ & Ground & SUSITNA & 63 & 23.5 & 147 & 12.5 \\
\hline
\end{tabular}

Notes

${ }^{1} \mathrm{~L}=$ liquefaction; $\mathrm{NL}=$ no liquefaction; $\mathrm{LS}=$ lateral spread 

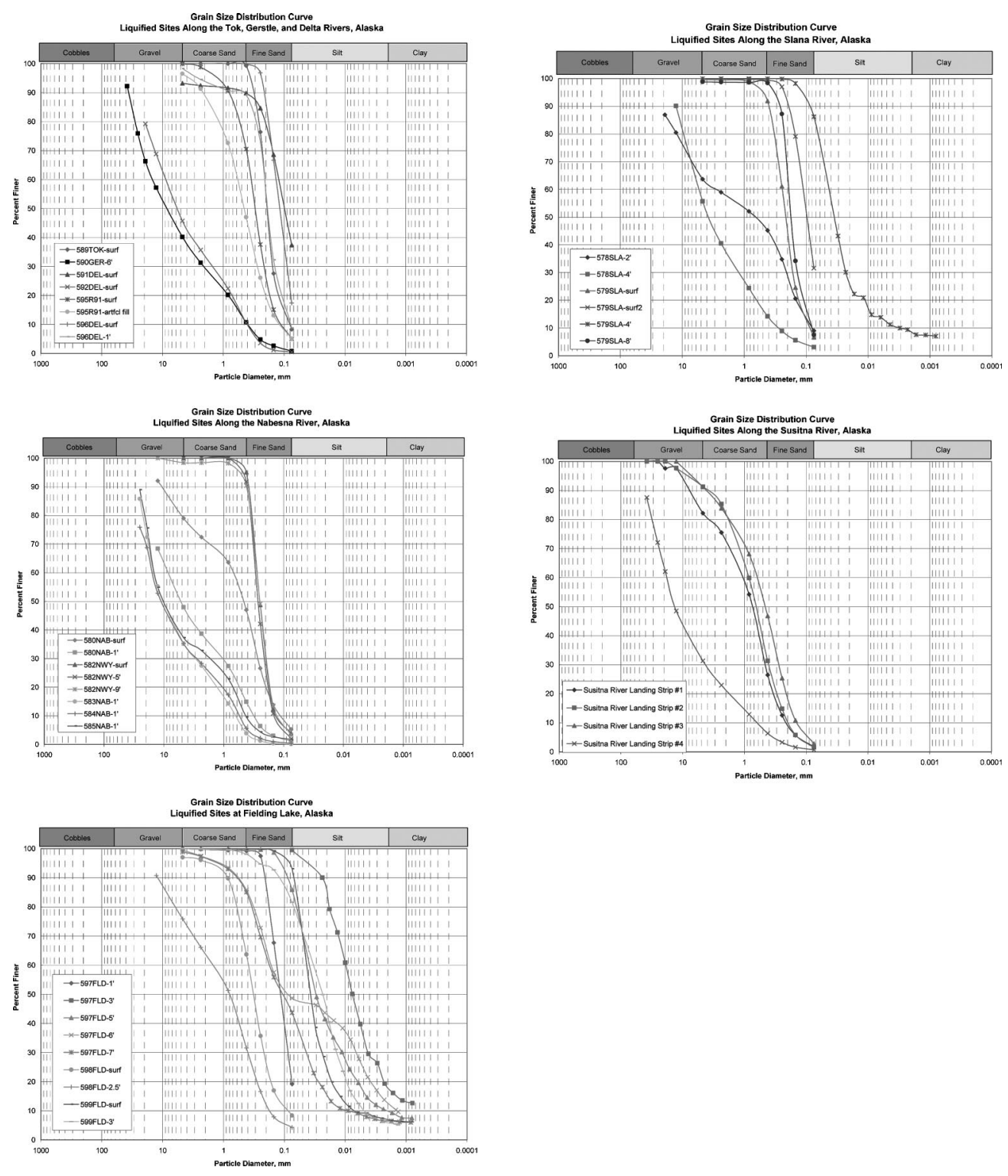

Figure A1. Cumulative grain size distribution curves for auger and surface samples taken at test sites throughout central Alaska. Refer to Table A2 for GPS locations of observed damage and test sites. 
Grain size distribution curves for all the samples are grouped by general location and are included in Figure A1.

\section{REFERENCES}

Boore, D. M., Joyner, W. B., and Fumal, T. E., 1997. Equations for estimating horizontal response spectra and peak acceleration from western North American earthquakes: A summary of recent work, Seismol. Res. Lett. 68 (1), 128-153.

Dreger, D., and Kaverina, A., 2000. Seismic remote sensing for the earthquake source process and near-source strong shaking: A case study of the October 16, 1999 Hector Mine earthquake, Geophys. Res. Lett. 27, 1941-1944.

Dreger, D. S., Oglesby, D. D., Harris, R., Ratchkovshi, N., 2004. Kinematic and dynamic rupture models of the November 3, 2002 Mw7.9 Denali, Alaska, earthquake, Geophys. Res. Lett. 31.

Eberhart-Phillips, D., Haeussler, P. J., Freymueller, J. T., Frankel, A. D., Rubin, C. M., Craw, P., Ratchkovski, N. A., Anderson, G., Carver, G. A., Crone, A. J., Dawson, T. E., Fletcher, H., Hansen, R., Harp, E. L., Harris, R. A., Hill, D. P., Hreinsdóttir, S., Jibson, R. W., Jones, L. M., Kayen, R., Keefer, D. K., Larsen, C. F., Moran, S. C., Personius, S. F., Plafker, G., Sherrod, B., Sieh, K., Sitar, N., and Wallace, W. K., 2003. The 2002 Denali fault earthquake, Alaska: A large magnitude, slip-partitioned event, Science 300, 1113-1118.

Ellsworth, W. L., Çelebi, M., Evans, J. R., Jensen, E. G., Kayen, R., Metz, M. C., Nyman, D. J., Roddick, J. W., Stephens, C. D., and Spudich, P., 2004. Near-field ground motion of the 2002 Denali fault, Alaska, earthquake recorded at Pump Station 10, Earthquake Spectra 20 (3), 597-615 (this issue).

Hall, W. J., Nyman, D. J., Johnson, E. R., and Norton, J. D., 2003. Performance of the transAlaska pipeline in the November 3, 2003 Denali fault earthquake, Proceedings of the Sixth U.S. Conference and Workshop on Lifeline Earthquake Engineering, ASCE Technical Council on Lifeline Earthquake Engineering, Long Beach, CA.

Harp, E. L., Jibson, R. W., Kayen, R. E., Keefer, D. K., Sherrod, B. L., Carver, G. A., Collins, B. D., Moss, R. E. S., and Sitar, N., 2003. Landslides and liquefaction triggered by the M7.9 Denali fault earthquake of 3 November 2002: GSA Today 13, 4-10.

International Code Council, 2002. 2003 International Building Code, Falls Church, VA.

Kayen, R., Thompson, E., Minasian, D., Collins, B., Moss, R., Sitar, N., and Carver, G., 2003. Geotechnical and surface wave investigation of liquefaction and strong motion instrumentation sites of the 2002 Denali fault, Mw 7.9, earthquake, EOS Trans. Am. Geophys. Union 84 (46), Fall Meet. Suppl., Abstract S12A-0381.

National Soil Services, Inc., 1971., Log of boring no. 10-6 and P-6, Pump Station No. 10, unpublished, dated April 18, 1971. Available at http://nsmp.wr.usgs.gov/borehole/ taps_logs.html

Oglesby, D. D., Dreger, D. S., Harris, R. A., Ratchkovski, N., and Hansen, R., 2004. Inverse kinematic and forward dynamic models of the 2002 Denali, Alaska earthquake, Bull. Seismol. Soc. Am. submitted to special issue.

Rix, G. J., Hebeler, G. L., and Orozco, M. C., 2002. Near-surface $V_{s}$ profiling in the New Madrid seismic zone using surface-wave methods, Seismol. Res. Lett. 73 (3), 380-393.

Wright, T. J., Lu, Z., and Wicks, C., 2003. Source model for the Mw 6.7, 23 October 2002, Nenana Mountain earthquake (Alaska) from InSAR, Geophys. Res. Lett. 30, 18.

Youd, T. L., Idriss, I. M., Andrus, R. D., Arango, I., Castro, G., Christian, J. T., Dobry, R., Liam 
Finn, W. D., Harder, Jr., L. F., Hynes, M. E., Ishihara, K., Koester, J. P., Laio, S. S. C., Marcuson, III, W. F., Martin, G. R., Mitchell, J. K., Moriwaki, Y., Power, M. S., Robertson, P. K., Seed, R. B., and Stokoe, II, K. H., 2001. Liquefaction resistance of soils: Summary report from the 1996 NCEER and 1998 NCEER/NSF workshops on evaluation of liquefaction resistance of soils, J. Geotech. Geoenviron. Eng. 127 (10), 817-833. 